Article

\title{
Fishmeal Dietary Replacement Up to 50\%: A Comparative Study of Two Insect Meals for Rainbow Trout (Oncorhynchus mykiss)
}

\author{
Federico Melenchón ${ }^{1}$, Eduardo de Mercado ${ }^{1}$, Héctor J. Pula ${ }^{2}$, Gabriel Cardenete ${ }^{2}$, Fernando G. Barroso ${ }^{3}$ (D), \\ Dmitri Fabrikov $^{3}$, Helena M. Lourenço ${ }^{4}$, María-Fernanda Pessoa ${ }^{5}$ (D), Leidy Lagos ${ }^{6}$, Pabodha Weththasinghe ${ }^{6}$, \\ Marcos Cortés ${ }^{7}$ and Cristina Tomás-Almenar ${ }^{1, *}$
}

check for updates

Citation: Melenchón, F.; de Mercado, E.; Pula, H.J.; Cardenete, G.; Barroso, F.G.; Fabrikov, D.; Lourenço, H.M.;

Pessoa, M.-F.; Lagos, L.;

Weththasinghe, P.; et al. Fishmeal Dietary Replacement Up to $50 \%$ : A Comparative Study of Two Insect Meals for Rainbow Trout (Oncorhynchus mykiss). Animals 2022, 12, 179. https://doi.org/10.3390/ ani12020179

Academic Editors: José M. Carral and María Sáez-Royuela

Received: 17 December 2021

Accepted: 10 January 2022

Published: 12 January 2022

Publisher's Note: MDPI stays neutral with regard to jurisdictional claims in published maps and institutional affiliations.

Copyright: (c) 2022 by the authors. Licensee MDPI, Basel, Switzerland. This article is an open access article distributed under the terms and conditions of the Creative Commons Attribution (CC BY) license (https:// creativecommons.org/licenses/by/ $4.0 /)$.
1 Agro-Technological Institute of Castilla y León, Ctra. Arévalo s/n, 40196 Segovia, Spain; melramfe@itacyl.es (F.M.); eduardo.mercado@inia.es (E.d.M.)

2 Department of Zoology, Campus Fuentenueva, Facultad de Ciencias, University of Granada, 18071 Granada, Spain; pula@ugr.es (H.J.P.); gcardenete@ugr.es (G.C.)

3 Department of Biology and Geology, University of Almería, 04120 Almería, Spain; fbarroso@ual.es (F.G.B.); df091@ual.es (D.F.)

4 Division of Aquaculture, Valorisation and Bioprospection, Portuguese Institute for Sea and Atmosphere (IPMA, IP), Av. Dr. Alfredo Magalhães Ramalho 6, 1495-165 Algés, Portugal; helena@ipma.pt

5 GeoBioTec, Departamento de Ciências da Terra, Faculdade de Ciências e Tecnologia, Nova School, 2829-516 Monte da Caparica, Portugal; mfgp@fct.unl.pt

6 Department of Animal and Aquacultural Sciences, Faculty of Biosciences, Norwegian University of Life Sciences, P.O. Box 5003, NO-1432 Ås, Norway; leidy.lagos@nmbu.no (L.L.); pabodha.weththasinghe@nmbu.no (P.W.)

7 Laboratory of Immunology, Centre of Aquatic Biotechnology, Department of Biology, Faculty of Chemistry and Biology, University of Santiago of Chile, Av. Bernardo O'Higgins 3363, Santiago 9170002, Chile; marcos.cortes@usach.cl

* Correspondence: critoal@gmail.com

Simple Summary: The reduction of dependence on fishmeal as a main protein source for aquafeeds remains a big problem in reaching sustainable aquaculture. Several alternatives to this ingredient are being tested and developed, insects being one of the most promising. The present study included two different insect species (black soldier fly, Hermetia illucens, and yellow mealworm, Tenebrio molitor) in the formulation of diets for rainbow trout (Oncorhynchus mykiss) against one typical fishmeal-based diet. Different parameters related to both the efficiency of these diets and their physiological repercussions were analysed. Yellow mealworm proved to be the best alternative for the growth and nutrition of rainbow trout, possibly due to some changes described in protein utilization and intestine histology, while other parameters revealed the possible usage of insect meals as functional ingredients due to their repercussions on preventing tissue damage.

Abstract: The demand of optimal protein for human consumption is growing. The Food and Agriculture Organization (FAO) has highlighted aquaculture as one of the most promising alternatives for this protein supply gap due to the high efficiency of fish growth. However, aquaculture has been facing its own sustainability problem, because its high demand for protein has been traditionally satisfied with the use of fishmeal (FM) as the main source. Some of the most promising and sustainable protein substitutes for FM come from insects. The present manuscript provides insight into an experiment carried out on rainbow trout (Oncorhynchus mykiss) with a 50\% replacement of FM with different larvae insect meals: Hermetia illucens (HI), and Tenebrio molitor (TM). TM showed better results for growth, protein utilization and more active digestive function, supported by intestinal histological changes. Liver histology and intermediary metabolism did not show relevant changes between insect meals, while other parameters such as antioxidant enzyme activities and tissue damage indicators showed the potential of insect meals as functional ingredients.

Keywords: black soldier fly; mealworm; fishmeal replacement; rainbow trout; aquaculture; fish nutrition 


\section{Introduction}

Albeit at a slower speed than some decades ago, the global population is expected to keep increasing and reach 8.5 billion in 2030, 9.7 billion in 2050, and 10.9 billion in 2100 [1]. As a consequence of this increment, the demand of adequate protein for human consumption is also increasing. Aquaculture is one of the most promising alternatives to satisfy this demand due to the high efficiency of fish growth [2], the rapid development of the aquaculture industry itself, and the adequate calories-protein ratio of fish [3]. However, because many of the fish cultivated for human consumption require high protein levels to grow appropriately, aquaculture has been facing its own sustainability problems in the last few decades. These protein requirements have been traditionally satisfied with the use of fishmeal (FM) from wild-caught fish and as a by-product of extractive fishing practices [4]. Due to the fast growth of aquaculture, these ingredients are considered as non-sustainable in the long term.

Many efforts have been carried out from both research and aquaculture industries to partially replace FM with sustainable ingredients in fish feeds, without impairing fish growth and while giving insight into these sustainable ingredients. Alternatives such as vegetable ingredients $[5,6]$, yeast $[7,8]$, or microalgae $[9,10]$ are some of the ingredients that are being studied currently. Following this line, the present study is focused on insects as one of the most interesting protein substitutes for FM [11-14]. Setting aside the interspecific differences, as well as the harvesting time of larvae [15], the amino acidic proportions of the most typically studied insects tend to match that of FM $[16,17]$. Insects also reproduce and grow easily, have very efficient growth ratios, and require low amounts of space and energy to be produced [18]. Hence, their potential as a good source of sustainable animal protein is promising. Because the Food and Agriculture Organization (FAO) has mentioned zero hunger, sustainable communities, and life below water as three of its 17 Sustainable Development Goals of the 2030 Agenda [19], it is easy to assume that both aquaculture and insect production might consequentially play important roles in the upcoming years or decades.

Several manuscripts have proven the efficiency of insect meals (IMs) in different fish species [20-24], revealing the importance of both the insect and the fish species involved. For salmonids, the inclusion of IMs in feeds is, in general, well accepted. As an example of unaffected growth, Terova [25] replaced up to 30\% FM with Hermetia illucens (HI) in rainbow trout feed (Oncorhynchus mykiss). In the case of Atlantic salmon (Salmo salar), it was already proven that FM could be replaced entirely, using $\mathrm{HI}$ as one of the chosen protein sources [26]. Another experience [27] tested two hydrolysed IMs (yellow mealworm, Tenebrio molitor (TM) and superworm, Zophobas morio) on fingerlings of sea trout (Salmo trutta m. trutta) at 40\% FM replacement and noticed almost no changes in growth or protein use. Moreover, another experiment [28] did not note changes in growth for rainbow trout, substituting FM completely with TM. These and other published data support the idea that, with the due differences among species, a partial replacement of FM with IM has no adverse effects on the growth of most fish. Moreover, functional properties such as a possible enhancement of both the immunological and the antioxidant systems have been attributed to IMs, possibly due to compounds such as chitin or its derivatives [14,21,29-33].

The European Commission approved the use of seven insects as ingredients in aquafeeds [34]. Due to their relative availability, HI and TM are two of the most broadly studied insects for animal nutrition. Thus, the IM industry has a big potential and requires research studies to validate the use of IMs as an alternative ingredient in feed for aquaculture.

Following the results of a previous study with 15-30\% FM replacement (5-10\% IM inclusion level) [32], but increasing the FM replacement to 50\% (18\% IM inclusion level) in feed for rainbow trout, the present manuscript provides insights on the effects of two different IMs for several aspects, from growth to final composition of the fillets, while evaluating the physiological status of the fish and their possible consequences on health and welfare status. 


\section{Materials and Methods}

\subsection{Experimental Diets}

Whole dried insects from two different species in larval stage, Hermetia illucens (HI; Entomotech S.L., Almería, Spain) and Tenebrio molitor (TM; Mealfood Europe S.L., Salamanca, Spain) were used for this study, processed as insect meals (IMs). IMs were analysed before the formulation of the diets (Table 1). A total of three isoproteic (43.3\%) and isolipidic $(17.4 \%)$ diets were formulated (Table 2$)$ : a control diet with no IM (C), and two diets with $18 \%$ diet inclusion (50\% fishmeal replacement) of the cited IMs: H18 (HI), and T18 (TM). Ingredients were provided by 'Lorca Nutrición Animal S.A.' (Murcia, Spain). Methionine and lysine were added to diets to meet the nutritional requirements of rainbow trout $[35,36]$, manufactured by LifeBIOENCAPSULATION S.L. (Almería, Spain), and extruded as pellets of $3 \mathrm{~mm}$. The dough was passed through a single screw laboratory extruder (Miltenz 51SP, JSConwell Ltd., Palmerston North, New Zealand). The extruder barrel had four sections, with a temperature per section of (from inlet to outlet) $100{ }^{\circ} \mathrm{C}, 95{ }^{\circ} \mathrm{C}, 90{ }^{\circ} \mathrm{C}$ and $85{ }^{\circ} \mathrm{C}$, respectively. Pellets were kept in a drying chamber at $30^{\circ} \mathrm{C}$ for $24 \mathrm{~h}$ (Airfrio, Almería, Spain) and stored in sealed plastic bags at $-20{ }^{\circ} \mathrm{C}$ until they were used.

Table 1. Proximate and amino acids compositions of insect meals (IMs).

\begin{tabular}{ccc}
\hline Proximate Composition & Hermetia ilucens (HI) & Tenebrio molitor (TM) \\
\hline Crude protein (\%) & 28.5 & 39.1 \\
Crude fat (\%) & 25.6 & 27.0 \\
Crude ash (\%) & 9.75 & 3.42 \\
Moisture (\%) & 8.00 & 5.00 \\
Calcium (g/Kg) & 35.2 & 0.93 \\
Phosphorus (g/Kg) & 7.00 & 7.50 \\
Calcium-phosphorus ratio & 5.03 & 0.12 \\
Chitin (\%) & 7.50 & 5.90 \\
\hline Amino acid composition (g/100 g IM) & & \\
Asp (aspartate) & 2.92 & 3.71 \\
Thr (threonine) & 0.95 & 1.44 \\
Ser (serine) & 1.43 & 2.49 \\
Glu (glutamate) & 3.19 & 4.98 \\
Pro (proline) & 1.58 & 3.04 \\
Gly (glycine) & 1.84 & 2.87 \\
Ala (alanine) & 2.37 & 3.92 \\
Cys (cysteine) & 0.13 & 0.24 \\
Val (valine) & 1.42 & 2.32 \\
Met (methionine) & 0.47 & 0.57 \\
Ile (isoleucine) & 0.91 & 1.31 \\
Leu (leucine) & 1.86 & 2.96 \\
Tyr (tyrosine) & 2.23 & 4.47 \\
Phe (phenylalanine) & 2.16 & 3.07 \\
His (histidine) & 1.07 & 1.77 \\
Lys (lysine) & 1.94 & 2.49 \\
Arg (arginine) & 1.24 & 1.81 \\
\hline
\end{tabular}


Table 2. Formulation, proximate, and amino acid composition of experimental diets.

\begin{tabular}{|c|c|c|c|}
\hline Ingredients (\%; on Wet Basis) & $\mathrm{C}$ & H18 & T18 \\
\hline Fishmeal & 35.9 & 18.0 & 18.0 \\
\hline HI meal & 0.00 & 18.0 & 0.00 \\
\hline TM meal & 0.00 & 0.00 & 18.0 \\
\hline Wheat gluten & 10.5 & 15.4 & 11.9 \\
\hline Soy protein concentrate & 15.5 & 18.3 & 17.0 \\
\hline Wheat meal & 16.4 & 11.5 & 17.0 \\
\hline Soy lecithin & 1.30 & 0.50 & 0.50 \\
\hline Fish oil & 12.2 & 9.50 & 9.00 \\
\hline Vitamins and minerals & 2.00 & 2.00 & 2.00 \\
\hline Goma guar & 2.00 & 2.00 & 2.00 \\
\hline Blood meal & 4.00 & 4.00 & 4.00 \\
\hline Methionine & 0.20 & 0.50 & 0.50 \\
\hline Lysine & 0.00 & 0.40 & 0.10 \\
\hline Total & 100 & 100 & 100 \\
\hline \multicolumn{4}{|c|}{ Proximate composition (\%; on wet basis) } \\
\hline Moisture & 7.43 & 7.74 & 7.21 \\
\hline Total crude protein & 43.9 & 42.8 & 43.1 \\
\hline Total crude fat & 17.2 & 17.1 & 17.9 \\
\hline Ash & 7.41 & 6.45 & 6.11 \\
\hline Calcium & 0.51 & 0.26 & 0.45 \\
\hline Phosphorus & 0.33 & 0.24 & 0.24 \\
\hline Calcium-phosphorus ratio & 1.6 & 1.1 & 1.9 \\
\hline \multicolumn{4}{|c|}{ Amino acid composition * $(\mathrm{g} / 100 \mathrm{~g}$ feed $)$} \\
\hline Asp (aspartate) & 2.89 & 1.86 & 2.29 \\
\hline Thr (threonine) & 1.65 & 1.25 & 1.38 \\
\hline Ser (serine) & 1.59 & 1.22 & 1.46 \\
\hline Glu (glutamate) & 6.55 & 5.96 & 5.96 \\
\hline Pro (proline) & 2.15 & 2.11 & 1.84 \\
\hline Gly (glycine) & 1.78 & 1.16 & 1.53 \\
\hline Ala (alanine) & 1.73 & 1.05 & 1.58 \\
\hline Cys (cysteine) & 0.68 & 0.67 & 0.64 \\
\hline Val (valine) & 2.07 & 1.65 & 1.87 \\
\hline Met (methionine) & 1.22 & 1.13 & 1.26 \\
\hline Ile (isoleucine) & 1.93 & 1.55 & 1.63 \\
\hline Leu (leucine) & 3.15 & 2.56 & 2.79 \\
\hline Tyr (tyrosine) & 1.11 & 0.87 & 1.42 \\
\hline Phe (phenylalanine) & 1.89 & 1.63 & 1.93 \\
\hline His (histidine) & 1.03 & 0.84 & 1.03 \\
\hline Lys (lysine) & 2.66 & 1.88 & 2.18 \\
\hline Arg (arginine) & 2.50 & 1.86 & 2.04 \\
\hline
\end{tabular}

Vitamin and mineral premix (\% unless otherwise specified): vitamin A 2,000,000 UI; vitamin D3: 200,000 UI; vitamin E: 1.2; vitamin K3: 0.26; vitamin B1: 0.3; vitamin B2: 0.3; vitamin B6: 0.2; vitamin B9: 0.15; vitamin B12; 0.001; vitamin H: 0.03; inositol: 5; betaine: 5; calcium pantothenate: 1; nicotic acid: 2; Co: 0.006; Cu: 0.09; Fe: 0.06; I: 0.005; Mn: 0.095; Se: 0.0001; Zn: 0.075; Ca: 19; K: 2.4; Na: 4.1. C: control diet (no IM inclusion); H18: 18\% Hermetia illucens inclusion (HI); T18: 18\% Tenebrio molitor inclusion (TM). * Calculated from basic amino acids of ingredients.

\subsection{Experimental Animals and Rearing Conditions}

A total of 360 female rainbow trout with an initial weight of $14.6 \pm 0.2 \mathrm{~g}$ from a commercial farm (Piscifactoría Fuente del Campillo, Guadalajara, Spain) were transported to the experimental facilities of the Aquaculture Research Centre of "Instituto Tecnológico Agrario de Castilla y León" (ITACyL). Fish stayed in acclimation for 15 days before the beginning of the growth trial, and then they were randomly allocated into 12 cylindrical fiberglass tanks (four replicas per treatment; $500 \mathrm{~L}$ ) of a recirculating system, in groups of 30 animals. Once a day (9 a.m.), fish were fed by hand until apparent satiation was reached (maximum of 3\% daily feed intake). During the growth trial (77 days), water temperature 
$\left(12.5 \pm 1{ }^{\circ} \mathrm{C}\right)$, water dissolved oxygen $(9.2 \pm 1 \mathrm{mg} / \mathrm{L})$, and room photoperiod (12 h light: $12 \mathrm{~h}$ dark) were monitored. Water ammonia and nitrite levels were analysed daily, and kept at optimal levels (ammonia $<0.1 \mathrm{mg} / \mathrm{L}$ and nitrite $<0.1 \mathrm{mg} / \mathrm{L}$ ). The care and handling of rainbow trout were conducted according to specific regulations: The Directive of the European Union Council (2010/63/EU) [37] and the Spanish Government (Real Decreto 53/2013) [38]. The experiment was approved previously by the Bioethical Committee of "ITACyL" (Authorization number: 2017/19/CEEA).

\subsection{Growth Trial and Samples Collection}

Mortality and feed intake were monitored on a daily basis. Fish were measured and weighed every 21 days through a simple biometry procedure with a graduated ictiometer $( \pm 0.1 \mathrm{~mm})$ and scale $( \pm 0.1 \mathrm{~g})$, being previously fasted for one day and anesthetized with tricaine methanesulfonate (MS-222; $180 \mathrm{mg} / \mathrm{mL}$ ). In order to take samples of the different tissues, the fish were sacrificed by an overdose of MS-222 (300 mg/mL).

Before the feeding trial, eight fish were randomly sacrificed to analyse the initial value of the protein in the fillet.

During the final two weeks of the experiment, faeces were gathered every $24 \mathrm{~h}$ in a settling column using a modified Guelph method [39], and frozen at $-80{ }^{\circ} \mathrm{C}$ until they were analysed. At the end of the experiment, eight fish per diet ( 2 fish per tank) were randomly sampled and sacrificed. According to time sequence, the following were collected to be analysed individually: skin mucus, blood, liver, stomach, intestine with pyloric caeca, and fillet samples. Skin mucus samples were collected by scraping the dorso-lateral surface of the fish skin from cranial to caudal according to de Mercado et al. [40] and frozen at $-80{ }^{\circ} \mathrm{C}$ until processing. Blood samples were collected with heparinized syringes and their plasma was separated by centrifugation at $3500 \times g$ and $4^{\circ} \mathrm{C}$, for $15 \mathrm{~min}$. Individual plasma samples were frozen at $-80^{\circ} \mathrm{C}$ until their analysis.

For enzyme determinations, samples were frozen in liquid nitrogen and kept at $-80{ }^{\circ} \mathrm{C}$ until they were analysed. For tumour necrosis factor-alpha determination (TNF- $\alpha$ ), distal intestine samples were kept in Allprotect Tissue Reagent (QiaGEn) and stored at $-20{ }^{\circ} \mathrm{C}$ until protein extraction. The samples for histomorphology analyses were fixed in $4 \%$ buffered formalin for $48 \mathrm{~h}$ before dehydration and processing. For chemical analyses, the samples were directly frozen at $-80^{\circ} \mathrm{C}$.

\subsection{Histomorphology}

\subsubsection{Samples Processing}

The fixed samples were dehydrated in increasing ethanol solutions $(25 \%, 50 \%, 75 \%$, and $100 \%)$ and embedded in synthetic paraffin. Histological sections $(3-4 \mu \mathrm{m})$ were obtained by a rotary microtome (FINESSE ME+ Thermo Scientific@, Waltham, MA, USA), stained by hematoxylin and eosin technique for histomorphology studies and observed with light microscopy. All of the evaluations were performed by graded objective lens in five random regions for each stained tissue section with an Olympus EP50 microscope camera and an Olympus CX31 microscope.

\subsubsection{Distal Intestine and Pyloric Caeca Histomorphology Analyses}

Quantitative studies included the measurement of heights of villi and enterocytes, as well as widths of villi, stratum compactum, muscular layers (longitudinal and circular), and lamina propria as mean of three measures (apical, intermediate, and basal). The level of inflammatory infiltration in lamina propria, the level of loss of supranuclear vacuolization of enterocytes, and the relative position of enterocyte nuclei were measured through a subjective analysis. 


\subsubsection{Liver Histomorphology Analysis}

Hepatocyte cytoplasm and hepatocyte nucleus measures were taken as quantitative variables. A qualitative analysis concerning the search of inflammatory patterns (necrosis and inflammation focuses) and hepatocyte intranuclear vacuolization was also carried out.

\subsection{Analytical Determinations}

For intermediary metabolism and antioxidant status, liver samples were individually homogenized in nine volumes of ice-cold $100 \mathrm{mM}$ Tris- $\mathrm{HCl}$ buffer, containing $0.1 \mathrm{mM}$ EDTA and $1 \mathrm{~g} / \mathrm{kg}(\mathrm{v} / \mathrm{v})$ Triton X-100, pH 7.8. This was followed by centrifugation at 30,000 $\times g$ for $30 \mathrm{~min}$, at $4{ }^{\circ} \mathrm{C}$. For further enzyme assays, the supernatants were stored at $-80{ }^{\circ} \mathrm{C}$ as aliquots.

The concentration of soluble protein in samples was determined by Bradford method [41], employing bovine serum albumin as a standard.

\subsubsection{Chemical Analyses}

AOAC methods [42] were used to analyse fat content and moisture of IMs, diets, and fish fillets. Protein content was determined with the Dumas method [43], using a nitrogen analyser (FP 528, LECO, St. Joseph, MO, USA), and with a conversion factor of 4.67 for HI, 4.75 for TM [44], and 6.25 for feeds and faeces. Acid-insoluble ash was used as marker in feeds and faeces to determine the apparent digestibility of the protein [45]. Phosphorus (P) was determined by molecular absorption spectrophotometry according to ISO standard [46], with a spectrophotometer (UV/Vis UV2, UNICAM, Cambridge, UK). Calcium was determined as described by Pessoa [47], with X-ray fluorescence method of Dispersive Energy. The method described by Gamage and Shahidi [48] was used to isolate chitin from IM, which was washed with acetone, dried, and weighed afterwards. For amino acids, samples of $\mathrm{HI}$ and TM were hydrolysed with $6 \mathrm{~N} \mathrm{HCl}$ for $22 \mathrm{~h}$ at $110{ }^{\circ} \mathrm{C}$ [16]. The determination was performed by ion-exchange liquid chromatography and postcolumn continuous reaction with ninhydrin (Biochrom 30; Cambridge, UK). Tryptophan was not determined.

\subsubsection{Digestive Enzymes Determination}

Intestine with pyloric caeca and stomach were processed separately to determine digestive enzymes. Samples were first individually homogenized at $4{ }^{\circ} \mathrm{C}$ with distilled water $(250 \mathrm{mg} / \mathrm{mL})$. Acid protease activity was determined from stomach extracts, while amylase and alkaline protease activities were determined from the intestine and pyloric caeca extracts. The activity of amylase was determined through the Somogy-Nelson method [49], with soluble starch $20 \mathrm{~g} / \mathrm{kg}$ as substrate, defining one unit of activity as the quantity of enzyme able to produce $1 \mu \mathrm{g}$ of maltose per minute and $\mathrm{mg}$ of protein. Walter method [50] was used to measure the activity of alkaline protease, employing casein $10 \mathrm{~g} / \mathrm{kg}$ as substrate. Anson method [51] was used to measure the activity of acid protease activity, with hemoglobin $5 \mathrm{~g} / \mathrm{kg}$ as substrate. For both proteases, one unit of activity was defined as $1 \mu \mathrm{g}$ of tyrosine produced per minute and $\mathrm{mg}$ of protein. The standard temperature for all digestive enzyme analyses was $37^{\circ} \mathrm{C}$.

\subsubsection{Liver Intermediary Metabolism}

The method described by Furné [52] was used to determine the enzymatic activity of fructose 1,6-bisphosphatase (FBPase; EC 3.1.3.11), pyruvate kinase (PK, EC 2.7.1.40), glutamate pyruvate transaminase (GPT; EC 2.6.1.2), glutamate oxaloacetate transaminase (GOT; EC 2.6.1.1), and glutamate dehydrogenase (GDH; EC 1.4.1.2). Enzymes were analysed at $25^{\circ} \mathrm{C}$, and changes in absorbance were monitored with a PowerWaveX microplate scanning spectrophotometer (BioTek Instruments, Winooski, VT, USA) to determine the enzyme activity. 


\subsubsection{Non-Specific Immune Status}

Plasma Immunological Determinations

Lysozyme activity was performed using a turbidometric method [53] with Micrococcus lysodeikticus (Sigma, St. Louis, MO, USA). After reaction for $20 \mathrm{~min}$ at $35^{\circ} \mathrm{C}$, the absorbance was measured at $450 \mathrm{~nm}$. A standard curve with hen egg-white lysozyme was used.

Total esterase activity was assayed according to Mashiter and Morgan [54] at $25^{\circ} \mathrm{C}$. P-nitrophenyl acetate $(0.8 \mathrm{mM})$ was used as a substrate, and $1.6 \mathrm{mM}$ acetazolamide as an inhibitor of carbonic anhydrase activity. The absorbance increase was measured at $405 \mathrm{~nm}$ for $5 \mathrm{~min}$, after incubation for $10 \mathrm{~min}$.

Anti-protease was measured according to Thompson [55]. The production of 4nitroaniline was determined by the variation of the OD (optical density) at $410 \mathrm{~nm}$ for $30 \mathrm{~min}$. Trypsin activity in absence of plasma was used as control (CAS 90002-07-7, Acofarma, Spain).

Phosphatase activity was determined according to Huang [56]. P-nitrophenyl phosphate (Sigma) was used as a substrate, a buffer at $\mathrm{pH} 10\left(\mathrm{NaHCO}_{3} / \mathrm{NaOH} 0.05 \mathrm{M}, \mathrm{MgCl}_{2} 1 \mathrm{mM}\right)$ was used for alkaline phosphatase activity, and a buffer at $\mathrm{pH} 5\left(\mathrm{CH}_{3} \mathrm{COOH} / \mathrm{CH}_{3} \mathrm{COOHNa}\right.$ $0.1 \mathrm{M}, \mathrm{MgCl}_{2} 1 \mathrm{mM}$ ) to measure acid phosphatase activity. The measurement was performed at $405 \mathrm{~nm}$ for $30 \mathrm{~min}$, at $37^{\circ} \mathrm{C}$.

Peroxidase activity was determined according to Mohanty and Sahoo [57]. A solution of $20 \mathrm{mM}$ TMB $\left(3,3^{\prime}, 5,5^{\prime}\right.$-Tetramethylbenzidine) was used as substrate. The samples were read at $450 \mathrm{~nm}$ after blocking reaction for $2 \mathrm{~min}$. Plasma-free standard samples were measured as controls. The activity was expressed in OD (optical density).

Total immunoglobulin was determined according to Panigrahi [58]. After precipitation with polyethylene glycol, the immunoglobulins were separated from the total proteins. Total immunoglobulin content was calculated by subtracting the protein content resulting from the total protein content in the untreated plasma.

\section{TNF- $\alpha$ Detection in Distal Intestine and Skin Mucus}

For protein extraction, samples of the distal intestine and skin mucus were homogenized using beads and an ice-cold lysis buffer (Tris $20 \mathrm{mM}$, NaCL $100 \mathrm{mM}$, Triton X-100 $0.05 \%$, EDTA $5 \mathrm{mM}$, protease inhibitor cocktail $1 \mathrm{X}$ ), in a bead mill homogenizer (Qiagen RETSCH tissuelyser). The homogenate was centrifuged for $25 \mathrm{~min}$, at $12,000 \times g$ and $4{ }^{\circ} \mathrm{C}$. The soluble proteins contained in the supernatant were stored at $-20{ }^{\circ} \mathrm{C}$ until use. The cytokine TNF- $\alpha$ was determined following the indirect ELISA method described by Morales-Lange [59], with slight modifications according to Weththasinghe [33]. Briefly, $100 \mu \mathrm{L}$ of sample diluted to $45 \mathrm{ng} / \mu \mathrm{L}$ in a carbonate buffer $\left(60 \mathrm{mM} \mathrm{NaHCO}_{3}, \mathrm{pH}\right.$ 9.6) were seeded into 96-well plates (NUNC MAXISORPTM, Invitrogen), and incubated overnight at $4{ }^{\circ} \mathrm{C}$. After blocking ( $5 \%$ Blotting-Grade Block, BioRad, Hercules, CA, USA; $2 \mathrm{~h}$ at $\left.37^{\circ} \mathrm{C}\right)$, plates were incubated for $90 \mathrm{~min}$ at $37^{\circ} \mathrm{C}$ with $50 \mu \mathrm{L}$ of the primary antibody (rabbit anti$\mathrm{TNF} \alpha$, diluted 1: 200). Next, $50 \mu \mathrm{L}$ of the secondary antibody (mouse anti-rabbit IgG-HRP, diluted 1: 7000) were added and incubated for $60 \mathrm{~min}$ at $37^{\circ} \mathrm{C}$. Finally, $100 \mu \mathrm{L}$ of chromagen substrate 3,3',5,5'- tetramethylbenzidine single solution (TMB, Thermofisher, Waltham, MA, USA) was added and incubated for $30 \mathrm{~min}$ at room temperature. The reaction was stopped with $50 \mathrm{~mL}$ of $1 \mathrm{~N}$ sulfuric acid and read at $450 \mathrm{~nm}$ on a Spectra Max microplate reader (Spectra Max M2; Molecular Devices, San José, CA, USA). The calibration curve was performed using serial dilutions of the corresponding epitope peptide ranging from $0 \mu \mathrm{g} / \mathrm{mL}$ to $1.2 \mu \mathrm{g} / \mathrm{mL}$.

\subsubsection{Liver Antioxidant Status and Fish Welfare Indicators}

The procedure described by Pérez-Jiménez [60] was followed to determine superoxide dismutase (SOD, EC 1.15.1.1), catalase (CAT, EC 1.11.1.6), glutathione peroxidase (GPX, EC 1.11.1.9), glutathione reductase (GR, EC 1.6.4.2), and glucose-6-phosphate dehydrogenase (G6PDH; EC 1.1.1.49). The enzyme analyses were carried out at $25^{\circ} \mathrm{C}$, and the enzyme activity was determined using a PowerWaveX microplate scanning spectrophotometer (BioTek 
Instruments, Winooski, VT, USA), through the monitorization of absorbance changes. Preliminary assays allowed the establishment of the optimal substrate and protein concentrations to measure the maximal activity of each enzyme. The millimolar extinction coefficients used for NADH/NADPH, DTNB, and $\mathrm{H}_{2} \mathrm{O}_{2}$ were $6.22,13.6$, and $0.039 / \mathrm{mM} \cdot \mathrm{cm}$, respectively. The enzyme needed to inhibit half of the ferricytochrome $\mathrm{C}$ reduction rate was defined as one unit of SOD activity. For other enzymes, the amount of enzyme required to transform $1 \mu \mathrm{mol}$ of substrate per minute was defined as one unit of enzyme activity. Malondialdehyde (MDA) level was used to quantify lipid peroxidation. MDA reacts in the presence of thiobarbituric acid to produce coloured thiobarbituric acid reacting substances (TBARS).

Plasma glucose and lactate levels were analysed with commercial colorimetric kits, following the instructions of the manufacturer (Glucose-TR, ref. 41011, Spinreact; Lactate, ref. 1001330, Spinreact). The absorbance was measured using a microplate reader (ELx800TM; BioTek Instruments, Inc., Winooski, VT, USA), in 96-well microplates.

\subsection{Statistical Analysis}

The software used for the statistical analyses was SAS system version 9.0 (SAS Institute Inc., Cary, NC, USA). A general linear model (PROC GLM) analysis of variance (ANOVA) was used to process the data, and the comparison of the means was performed by a Tukey test. Differences were considered significant when the $p$-value was $<0.05$. Values are showed as mean \pm standard error of the mean.

\section{Results and Discussion}

\subsection{Growth Performance}

In general, the performance of all diets was within normal values, with an efficient FCR (Table 3). Fish fed with T18 showed the best overall growth performance with very similar values to $\mathrm{C}$ while $\mathrm{H} 18$ showed lower numbers for growth, being statistically different from $\mathrm{T} 18$, or even to $\mathrm{C}$ when talking about SGR, FCR, and the apparent digestibility coefficient of the protein $\left(\mathrm{ADC}_{\text {prot }}\right)$. Even though there are small discrepancies in the literature about the performance of $\mathrm{HI}$ as an ingredient for fish [61-64], the present results seem to follow the general conclusions of other trials in rainbow trout. Rainbow trout seem to have a higher tolerance to the inclusion of TM in diets $[65,66]$ than that of HI $[61,67]$, which could be due to the different levels of chitin in the composition of the insects, or their amino acid profiles. Chitin might have a positive influence over fish physiology as a functional ingredient [68], but the presence of this molecule tends to lower the digestibility of crude protein $[69,70]$. Because HI has higher levels of chitin in its body composition than TM (Table 1), this, together with results in other experiences $[61,65,67,71]$ suggest that a $15-18 \%$ inclusion of $\mathrm{HI}$ in rainbow trout feed is a possible maximum level of inclusion for this species, while an $18 \%$ of TM or even more, is still compatible with optimal growth performance. In addition, the digestibility of the protein was higher in TM than HI; although the amino acid profile between IMs differed, the diets were supplemented with methionine and lysine to cover the nutritional requirements. This should had led to a similar growth between insect-based treatments, but the higher growth of T18 over H18 means that its higher digestibility played an important role, and consequently led to a higher growth than HI. 
Table 3. Growth performance, protein utilization, and biometric indices of rainbow trout fed experimental diets.

\begin{tabular}{cccccc}
\hline Growth Performance & C & H18 & T18 & SEM & $p$-Value \\
\hline IBW (g) & 14.3 & 14.8 & 14.7 & 0.22 & 0.325 \\
IBL (cm) & 11.1 & 11.2 & 11.2 & 0.05 & 0.377 \\
\hline FBW (g) & $76.4^{\mathrm{a}, \mathrm{b}}$ & $69.4^{\mathrm{b}}$ & $81.9^{\mathrm{a}}$ & 2.41 & 0.016 \\
FBL (cm) & $18.0^{\mathrm{a}, \mathrm{b}}$ & $17.6^{\mathrm{b}}$ & $18.5^{\mathrm{a}}$ & 0.16 & 0.010 \\
SGR (\%/day) & $2.17^{\mathrm{a}}$ & $2.00^{\mathrm{b}}$ & $2.23^{\mathrm{a}}$ & 0.04 & 0.011 \\
DFI (g/100 g fish·day) & $1.57^{\mathrm{a}}$ & 1.62 & 1.57 & 0.02 & 0.267 \\
FCR & $0.90^{\mathrm{a}}$ & $0.98^{\mathrm{b}}$ & $0.88^{\mathrm{a}}$ & 0.02 & 0.006 \\
\hline Protein utilization & & & & \\
\hline PER & $2.49^{\mathrm{a}, \mathrm{b}}$ & $2.34^{\mathrm{b}}$ & $2.58^{\mathrm{a}}$ & 0.05 & 0.015 \\
PPV (\%) & 49.2 & 48.6 & 51.8 & 1.23 & 0.196 \\
ADC prot $(\%)$ & $92.6^{\mathrm{a}}$ & $81.0^{\mathrm{b}}$ & $91.2^{\mathrm{a}}$ & 1.05 & $<0.0001$ \\
\hline Biometric indices & & & & \\
\hline CF (g/cm ${ }^{3}$ ) & 1.31 & 1.28 & 1.3 & 0.01 & 0.461 \\
HSI (\%) & 1.26 & 1.44 & 1.29 & 0.07 & 0.244 \\
VSI (\%) & 14.3 & 15.9 & 14.5 & 0.42 & 0.051 \\
\hline
\end{tabular}

C: control diet (no IM inclusion); H18: 18\% HI inclusion; T18: 18\% TM inclusion. IBW: initial body weight IBL: initial body length; FBW: final body weight; FBL: final body length; SGR (specific growth rate) $=((\mathrm{ln}$ FBW$\ln \mathrm{IBW}) /$ days $) \cdot 100 ;$ DFI (daily feed intake) = (daily feed consumption (g)/biomass (g) at time) 1 100; FCR $($ feed conversion ratio $)=($ total feed intake $(\mathrm{g}) /($ FBW-IBW $)) ;$ PER $($ protein efficiency ratio $)=($ total weight gain $(\mathrm{g}) /$ protein intake $(\mathrm{g}))$; PPV (productive protein value $)=(($ protein gain $(\mathrm{g}) /$ protein intake $(\mathrm{g})) \cdot 100) ; \mathrm{ADC}$ prot (apparent digestibility coefficient of the protein $)=100-(($ marker in diet $(\mathrm{g}) /$ marker in faeces $(\mathrm{g})) \cdot(\%$ protein in faeces $/ \%$ protein in diet $) \cdot 100) ; \mathrm{CF}$ (condition factor $)=\left(\right.$ weight $(\mathrm{g}) /$ length $\left.^{3}(\mathrm{~cm})\right) \cdot 100 ;$ HSI (hepatosomatic index $)=($ wet liver weight $/$ FBW $) \cdot 100$; VSI (viscerosomatic index) $=($ wet visceral weight $/ \mathrm{FBW}) \cdot 100 .{ }^{\mathrm{a}, \mathrm{b}} \mathrm{Show}$ statistically significant differences among diets $(p<0.05)$; Values are expressed as mean \pm standard error of the mean (SEM; $n=4$ tanks per diet).

The mortality during the trial was around $3 \%$ without remarkable differences between diets (data not shown).

\subsection{Histomorphology}

\subsubsection{Distal Intestine and Pyloric Caeca}

On distal intestine (Figure 1), no significant differences were described for villi, stratum compactum, longitudinal muscular layer, or lamina propria widths. Villi height was higher for T18 fish than H18 $(p<0.05)$, with an intermediate value for $\mathrm{C}$ fish. Enterocyte height was higher in T18 than in C $(p<0.05)$, with no significant differences between H18 and T18. The circular muscular layer was wider on $\mathrm{C}$ than on $\mathrm{H} 18$, while the total muscular layer was wider on $C$ than on both IM treatments $(p<0.05)$. For qualitative analyses (Figure 2$)$, slightly higher levels of both inflammatory infiltration and loss of intracellular vacuolization were highlighted for $\mathrm{C}$ diet. The different degrees of supranuclear vacuolization did not affect the enterocyte structure because most nuclei were positioned on the basal part of the enterocytes, showing no differences between treatments. 

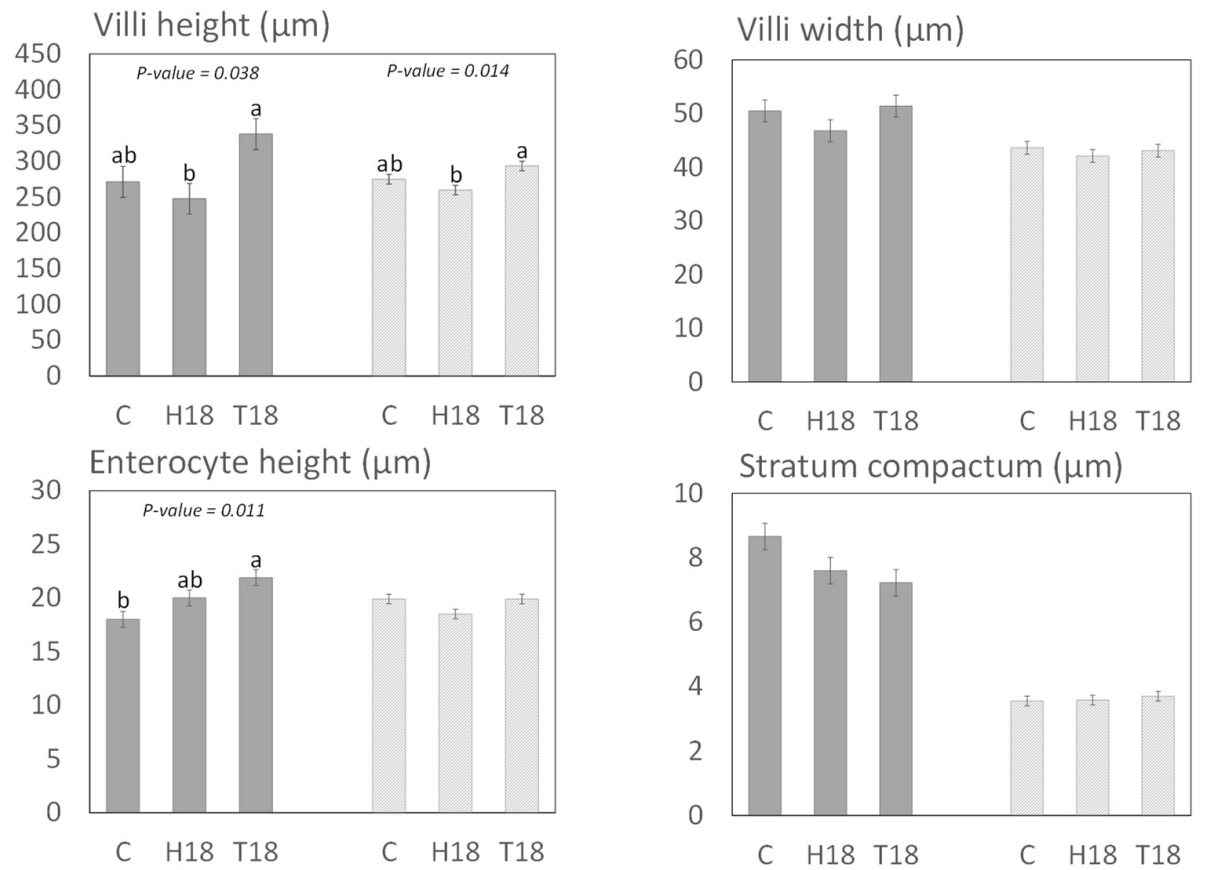

Circular muscular layer $(\mu \mathrm{m})$

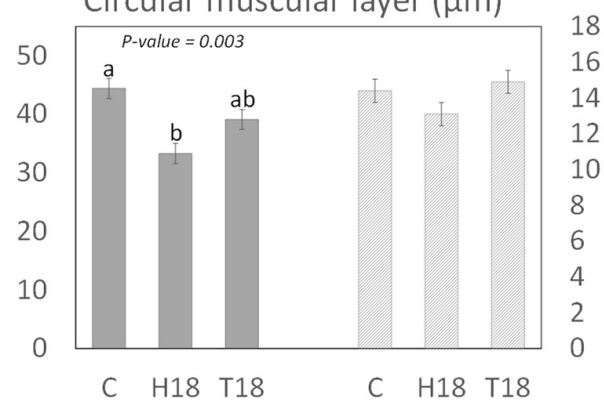

Longitudinal muscular layer ( $\mu \mathrm{m})$
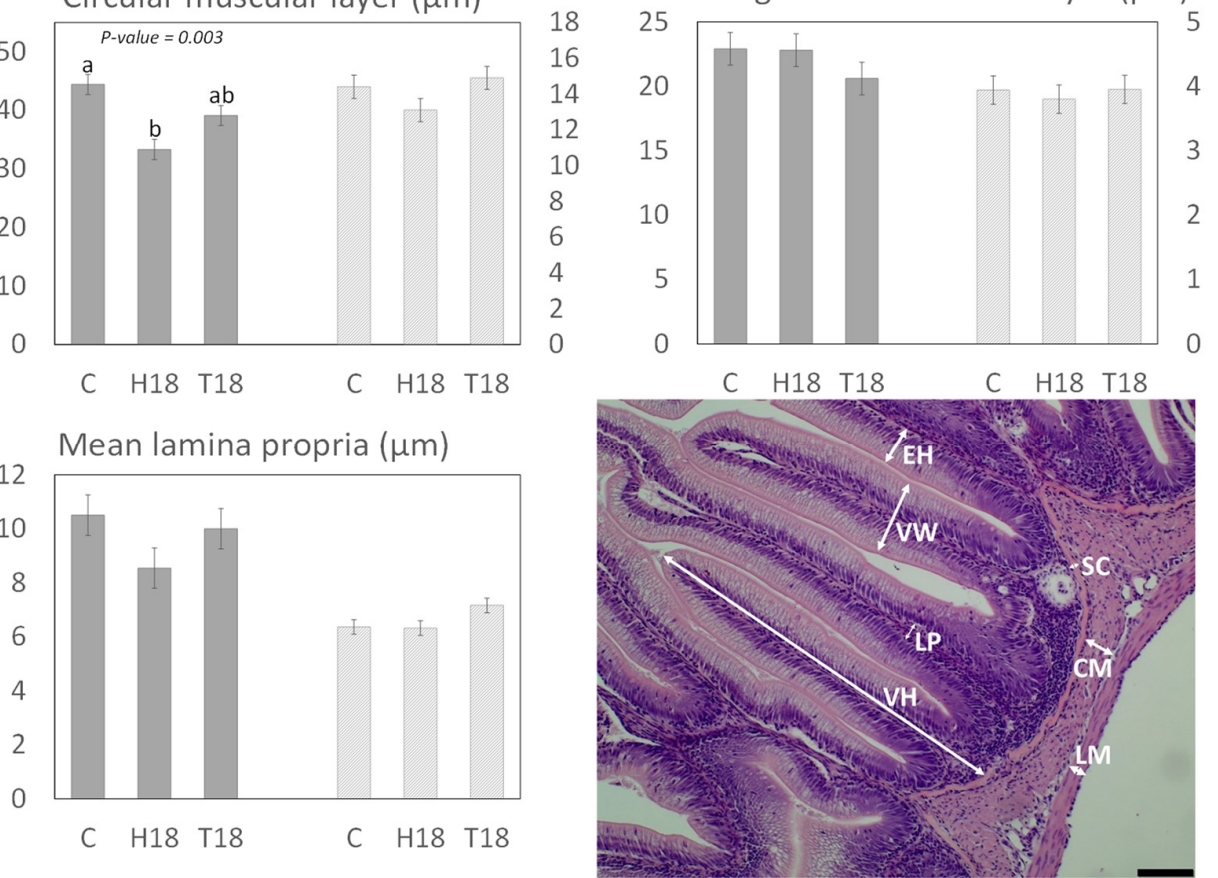

Figure 1. Histomorphology of rainbow trout gut. C: control diet; H18: $18 \% \mathrm{HI}$ inclusion; T18: $18 \%$ TM inclusion. Grey bars: distal intestine measures; striped bars: pyloric caeca measures. a, b Show statistically significant differences among diets $(p<0.05)$; Values expressed as mean \pm standard error of the mean (SEM; $n=4$ tanks per diet, 2 fish per tank). Microphotograph representative of measures for gut: villi height (VH), villi width (VW), enterocyte height (EH), stratum compactum (SC), circular muscular layer width (CM), longitudinal muscular layer width (LM), lamina propria width (LP). Scale bar $=100 \mu \mathrm{m}$. 


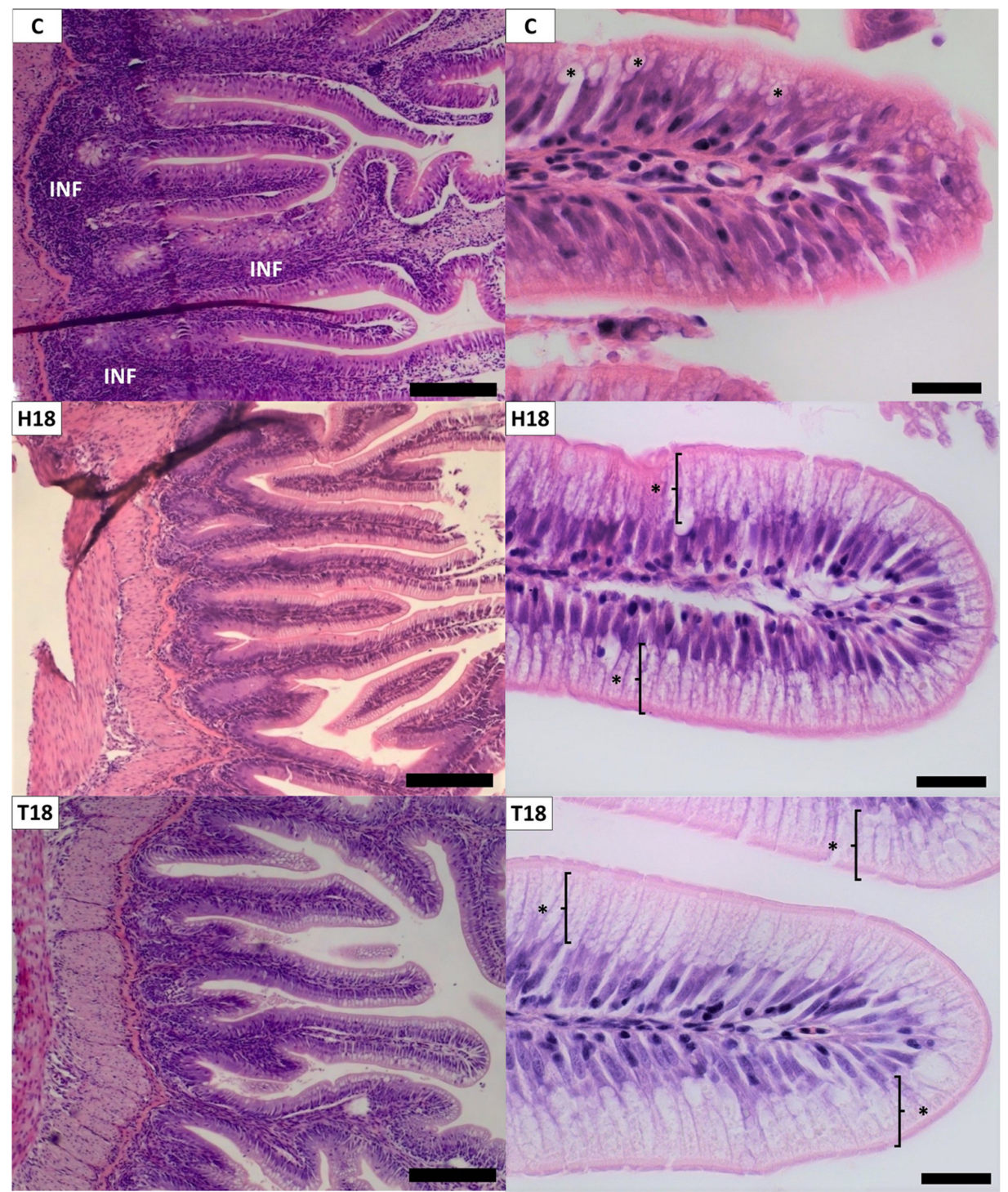

Figure 2. Histomorphology of rainbow trout distal intestine. C: control diet (no IM inclusion); H18: 18\% HI inclusion; T18: 18\% TM inclusion. Microphotographs of qualitative analyses: left photographs represent a comparative view of inflammatory infiltration (INF), pictures taken at $40 \times$ magnification, scale bars $=100 \mu \mathrm{m}$; right photographs represent a comparative view of vacuoles (marked with asterisks) in enterocytes, pictures taken at $400 \times$ magnification. Scale bars $=10 \mu \mathrm{m}$.

Few significant differences were found in pyloric caeca compared to the distal intestine. T18 showed the highest values for villi height (compared to H18; $p<0.05$ ), while the rest of the results remained stable (Figure 1). For the qualitative analyses, no differences were observed for inflammatory infiltration or intracellular vacuolization, and most nuclei were described on the intermediate part with no differences between treatments.

The histology of insect-fed fish intestine has been extensively studied in the last few years $[27,33,63,72-74]$. However, due to the large number of variables involved in the studies, such as the fish species, the insect used to elaborate the feeds, the chosen intestine sections, or the analysed parameters, there is still work to be conducted. Villi height is one of the most frequently analysed parameters, being an indicator usually associated with gut health and growth performance. In this way, the results of this study match partially those of the current literature, because it has been described that similar inclusions of $\mathrm{HI}$ in fish feed tend to decrease villi height $[67,71,75-77]$. There are other cases in which no changes or even an increase in villi height was described with the addition of HI meal $[63,78,79]$. 
The case of TM is less studied and it seems that, with one exception [63], most studies describe no changes in villi height when dealing with this ingredient $[27,73,80]$.

On pyloric caeca, the results were similar. However, this is a less studied variable for insect-fed fish, and to our knowledge, only two studies evaluated this parameter after a growth trial with HI treatments; one that matched the data of this study [77], and one that offered opposite results [81]. Considering that digestive efficiency and growth are directly related to gut anatomy alterations such as a decrease in the absorption surface [82-84], it is no surprise that the results of the present manuscript agree with the lower growth performance and protein digestibility described for $\mathrm{HI}$, as well as the higher results on TM.

The circular muscular layer was also affected in the present study. The main finding was a decrease in the width for $\mathrm{H} 18$ with significant difference with respect to $\mathrm{C}$ diet $(p<0.05)$. Because contraction and relaxation of circular and longitudinal muscular layers lead to peristaltic movements, a different width of the circular muscular layer could alter the movement of the feed along the gut, affecting the intestinal bacterial growth [85] and ultimately the digestibility of the nutrients, consistent with the lower digestibility of the protein observed in fish fed with H18. Similar results were showed by Lu [76], while other authors have not described changes in muscular layer width $[27,79,81]$; there is even a case in which different insect species gave different results [63] with the inclusion of IMs. This divergence of data is probably caused by the different species of fish used.

It is interesting to notice that the differences in the degree of enterocyte supranuclear vacuoles loss (fewer vacuoles in $\mathrm{C}$ ) are in consonance with the results on enterocyte height (lower in C, with a significant difference between C and T18). The presence or absence of lipidic vacuoles in enterocytes has been related to their height for other ectothermic species [86,87]. In this way, the different nature of the fat between diets (insect fat in H18 and T18), and their absorption process may have played an important role in the degree of supranuclear lipidic vacuoles in enterocytes. Furthermore, the work of Kumar [88] described how IMs could cause a protective effect against the problems of soybean meal [89] in salmonids. Considering that $\mathrm{C}$ diet also showed a slightly higher submucosa inflammatory infiltration, the lower degree of vacuolization and the consequential lower enterocyte height with respect to IM diets could be due to the lack of this protective effect. The three diets had a relatively high amount of vegetable ingredients, but even though H18 and T18 had the highest amounts of these ingredients, they showed the lowest levels of inflammatory signs.

\subsubsection{Liver}

No significant differences were found in any of the measured variables: hepatocyte nucleus and cytoplasm diameters, inflammatory patterns, or level of hepatocyte vacuolization (Figure 3). Liver histology has also been extensively studied for insect-fed fish $[71,72,74,75,81]$. One of the most frequent findings in several fish species, including rainbow trout, is that an increasing proportion of IMs in the feed tends to increase the number of lipidic vacuoles in hepatocytes, while other related variables are mostly unaffected $[71,78,81]$. This discrepancy with our results could be due to the different size and feeding period of the fish involved, because the cited study in rainbow trout was performed with bigger fish. The work of Kumar [88], however, had similar conclusions to those of the present study. 

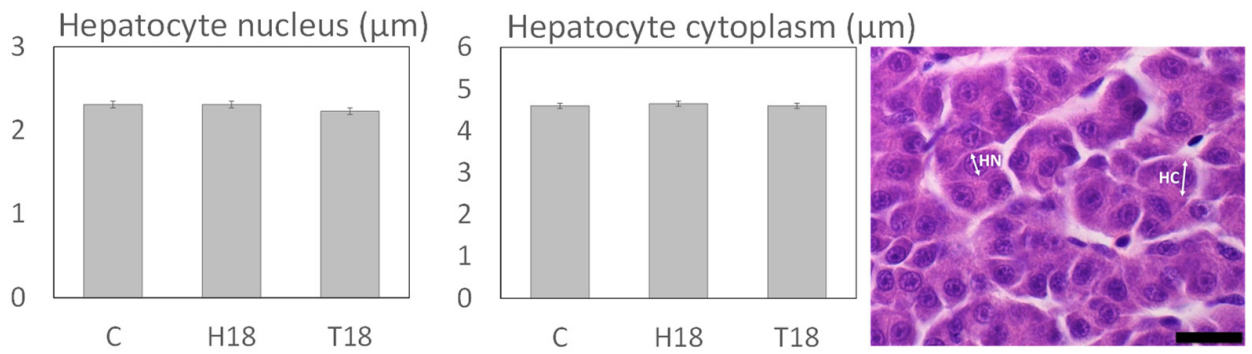

Figure 3. Histomorphology of rainbow trout liver. C: control diet (no IM inclusion); H18: 18 \% HI inclusion; T18: $18 \%$ TM inclusion. Values are expressed as mean \pm standard error of the mean (SEM; $n=4$ tanks per diet, 2 fish per tank). Microphotograph representative of measures for liver: hepatocyte nucleus $(\mathrm{HN})$ and hepatocyte cytoplasm $(\mathrm{HC})$ diameters. Scale bar $=10 \mu \mathrm{m}$.

\subsection{Digestive Enzymes}

Acidic proteases showed no significant differences between treatments (Table 4; $p>0.05)$, while alkaline proteases and amylase showed significant increases in T18 treatment. The higher values of alkaline proteases for T18 are in consonance with the bigger digestibility of the protein demonstrated by this diet over H18 (Table 1). Because IM diets showed higher values of alkaline proteases than $C$, as well as lower acidic-alkaline ratios (non-statistically significant for H18), this supports the idea that insect-based diets suffered a more active digestion in the intestine. Contrarily, the work of Coutinho [23] showed a lower activity of total alkaline protease, trypsin, and lipase even on low inclusions of TM (defatted) for meagre (Argyrosomus regius). However, this work and the work of Guerreiro [22] showed that meagre might not be the best candidate to use IMs as a source of protein, which supports the point that differences between species must always be considered. In the present study, the increase in alkaline proteases could have been caused by the added effort of having to break the $\beta(1-4)$ glycosidic bonds of chitin polymers, and especially its metabolites, because it was proven that chitinase activity is low in rainbow trout [90]. However, because chitinase (mostly located in the stomach) and chitobiase (mostly located in the intestine) activities were not measured, this would remain as a theory to encourage more future research.

Table 4. Digestive enzymes of rainbow trout fed experimental diets.

\begin{tabular}{cccccc}
\hline $\begin{array}{c}\text { Digestive Enzymes (U/mg } \\
\text { Protein) }\end{array}$ & C & H18 & T18 & SEM & $p$-Value \\
\hline Acidic proteases & $400.9^{\mathrm{b}}$ & 314.9 & 383.4 & 47.6 & 0.470 \\
Alkaline proteases & $82.2^{\mathrm{b}}$ & $117.0^{\mathrm{b}}$ & $263.5^{\mathrm{a}}$ & 23.4 & 0.001 \\
Acidic-alkaline ratio & $6.36^{\mathrm{a}}$ & $2.60^{\mathrm{a}, \mathrm{b}}$ & $1.49^{\mathrm{b}}$ & 0.90 & 0.009 \\
Amylase & $81.5^{\mathrm{b}}$ & $85.1^{\mathrm{a}, \mathrm{b}}$ & $139.5^{\mathrm{a}}$ & 15.2 & 0.043 \\
\hline
\end{tabular}

C: control diet (no IM inclusion); H18: 18\% HI inclusion; T18: 18\% TM inclusion. ${ }^{\mathrm{a}, \mathrm{b}}$ Show statistically significant differences among diets $(p<0.05)$; Values are expressed as mean \pm standard error of the mean (SEM; $n=4$ tanks per diet, 2 fish per tank).

The results for amylase activity follows closely the tendency of a previous study [32]. It has been described that amylase activity increases with the amount of carbohydrates in the diet [91]. Moreover, Rapatsa and Moyo already proved [92,93] that higher levels of Imbrasia belina meal increased the levels of amylase, which was conferred to the remaining vegetable contents of Imbrasia belina, more than to the intrinsic components of that insect. Vegetables are the most common substrates for the feeding of insects. As part of the private knowledge of the insect provider, these data are not available in the present study, but the results in the amylase activity could be due, on the one hand, to different feeding habits of the insects, and on the other hand, to the different levels of wheat meal between H18 and T18 diets. 


\subsection{Liver Intermediary Metabolism}

No differences were found between treatments for any of the measured enzymes (FBPase, PK, GPT, GOT and GDH), which means that intermediary metabolism in the liver was mostly unaffected (Table 5). As stated previously, protein use (Table 3) was in general more efficient on $\mathrm{T} 18$ than on $\mathrm{H} 18$, which gives the idea that protein availability was better for fish fed with T18. The literature concerning the analysis of intermediary liver metabolism after a feeding trial with IMs is scarce, but supports the point that these ingredients do not disrupt the function of these enzymes [23,28,94,95]. In a previous experience [32] with similar diets and rearing conditions, but with $10 \%$ inclusion level of IMs, an increase in GOT activity was observed; in the present study, even though T18 showed a very similar trend ( $p$-value $=0.059)$, the ANOVA did not reveal a significant difference. Considering that liver histology did not show differences either, this also supports the present data.

Table 5. Intermediary metabolism enzymes in liver of rainbow trout fed experimental diets.

\begin{tabular}{cccccc}
\hline Enzymes (mU/mg Protein) & C & H18 & T18 & SEM & $p$-Value \\
\hline Fructose 1,6- biphosphatase & 26.6 & 22.8 & 27.7 & 4.49 & 0.724 \\
$\begin{array}{c}\text { (FBPase) } \\
\text { Pyruvate kinase (PK) }\end{array}$ & 55.1 & 50.2 & 64.9 & 6.84 & 0.346 \\
$\begin{array}{c}\text { Glutamate pyruvate transaminase } \\
\text { (GPT) }\end{array}$ & 329.3 & 371.5 & 333.2 & 30.1 & 0.568 \\
$\quad \begin{array}{c}\text { Glutamate oxaloacetate } \\
\text { transaminase (GOT) }\end{array}$ & 270.3 & 169.3 & 326.3 & 40.1 & 0.059 \\
Glutamate dehydrogenase (GDH) & 574.6 & 379.4 & 523.0 & 65.9 & 0.151 \\
\hline
\end{tabular}

C: control diet (no IM inclusion); H18: 18\% HI inclusion; T18: 18\% TM inclusion. Values are expressed as mean \pm standard error of the mean (SEM; $n=4$ tanks per diet, 2 fish per tank).

\subsection{Non-Specific Immune Status}

The immune status was evaluated in different tissues. Tumour necrosis factor-alpha (TNF- $\alpha$ ) was determined as a pro-inflammatory indicator [96] in distal intestine, as a first immune barrier from which an immune response can be initiated [97], and in skin mucus, for its role in innate immunity and fish health [98]. In addition, different parameters in plasma related to non-specific immune responses were determined.

No significant differences were found between treatments for TNF- $\alpha$ in distal intestine and skin mucus, or for lysozyme, esterase, anti-protease, alkaline phosphatase, peroxidase, or total immunoglobulins (IG) in plasma (Table 6).

Table 6. Non-specific immune parameters of rainbow trout fed experimental diets.

\begin{tabular}{cccccc}
\hline Immune Parameters & C & H18 & T18 & SEM & $p$-Value \\
\hline TNF- $\alpha$ DI & 0.43 & 0.36 & 0.59 & 0.08 & 0.189 \\
TNF- $\alpha$ SM & 0.75 & 0.37 & 0.52 & 0.11 & 0.105 \\
Lysozyme & 4.76 & 5.03 & 3.95 & 0.47 & 0.288 \\
Esterase & 1014.0 & 1114.9 & 1451.5 & 228.9 & 0.405 \\
Acid phosphatase & $882.1^{\mathrm{a}}$ & $791.2^{\mathrm{a}, \mathrm{b}}$ & $581.9 \mathrm{~b}$ & 53.9 & 0.009 \\
Alkaline phosphatase & 2350.4 & 2215.5 & 1780.8 & 291.6 & 0.392 \\
Anti-protease activity & 91.8 & 101.2 & 103.7 & 7.56 & 0.525 \\
Peroxidase & 0.58 & 0.69 & 0.47 & 0.08 & 0.223 \\
Total Immunoglobulins & 12.2 & 14.5 & 16.3 & 1.51 & 0.205 \\
\hline
\end{tabular}

C: control diet (no IM inclusion); H18: 18\% HI inclusion; T18: 18\% TM inclusion. TNF- $\alpha$ D.I.: Concentration of Tumour Necrosis Factor alpha in distal intestine; TNF- $\alpha$ S.M.: Concentration of Tumour Necrosis Factor alpha in skin mucus expressed as $\mu \mathrm{g} / \mathrm{mL}$; Lysozyme activity expressed as $\mu \mathrm{g} / \mathrm{mL}$ HEWL (Hen Egg White Lysozyme); Esterase, acid and alkaline phosphatases as $\mathrm{mU} / \mathrm{mg}$ protein; anti-protease activity as $\mathrm{U}$ anti-protease/mg protein; peroxidase as $\mathrm{U} / \mathrm{mg}$ protein; total $\mathrm{IG}$ as $\mathrm{mg} / \mathrm{mL}$. ${ }^{\mathrm{a}}$, b Show statistically significant differences among diets $(p<0.05)$. Values are expressed as mean \pm standard error of the mean (SEM; $n=4$ tanks per diet, 2 fish per tank). 
The only statistically significant difference was on acid phosphatase in plasma, where T18 showed the lowest level, being different to $C(p<0.05$; Table 6$)$. Acid phosphatase is related to tissue damage in other species $[99,100]$. IMs are known for causing varied effects on the immunological system of fish, while the precise mechanisms that produce them are still unknown $[14,30,33,88]$. In general, the immunostimulant effect of Ims is well accepted $[30,101,102]$, and a frequent justification for this is the influence of chitin and its derivatives, together with the presence of antimicrobial peptides in insects [13,103]. However, a publication by $\mathrm{Xu}$ [104] described how the replacement of soybean oil with an $\omega-3$ enriched insect oil modified the genetic expression of IL-1 $\beta$, IL-10, and TNF- $\alpha$ on the liver and kidney of juvenile mirror carp, as well as the amount of serum lysozyme. Moreover, Kumar [88] carried out two parallel experiments, one based on the addition of HI meal, and one on the replacement of fish oil with insect oil, and described different results for the same immunological parameters and the same organs of rainbow trout. Because the immunological system is complex and multifactorial, the different components of IMs such as chitin, insect fat, or other that might not be considered, could lead to very different interactions with it. Even though these immunological benefits are usually attributed to IMs, its chitin, or both $[30,101]$, concluding results will not be reached until the precise mechanisms involved are described.

\subsection{Liver Antioxidant Status and Fish Welfare Indicators}

With the exception of GPx activity, which was higher for C than for IM-based diets $(p<0.05)$, T18 showed an overall more active antioxidant status. There were no differences for G6PDH or GR. SOD activity was higher in T18 than in C and H18 $(p<0.05)$. Higher levels of CAT activity were highlighted in T18 than in H18, and lower levels of MDA are described in T18 than in C diet $(p<0.05)$. No differences were found between treatments for glucose or lactate plasmatic levels (Table 7).

Table 7. Liver antioxidant performance and fish welfare plasmatic parameters of rainbow trout fed experimental diets.

\begin{tabular}{|c|c|c|c|c|c|}
\hline $\begin{array}{c}\text { Antioxidant Enzymes and Lipid } \\
\text { Peroxidation }\end{array}$ & C & H18 & T18 & SEM & $p$-Value \\
\hline Superoxide Dismutase (SOD) & $208.1^{b}$ & $209.7^{b}$ & $273.3^{a}$ & 15.3 & 0.023 \\
\hline Catalase (CAT) & $186.5^{a, b}$ & $167.7^{\mathrm{b}}$ & $216.7^{\mathrm{a}}$ & 11.6 & 0.043 \\
\hline Glutathione Peroxidase (GPx) & $12.2^{\mathrm{a}}$ & $10.1^{\mathrm{b}}$ & $9.85^{b}$ & 0.32 & 0.001 \\
\hline Glutathione Reductase (GR) & 7.02 & 7.82 & 6.36 & 0.46 & 0.136 \\
\hline $\begin{array}{c}\text { Glucose-6-phosphate } \\
\text { dehydrogenase (G6PDH) }\end{array}$ & 43.2 & 41.5 & 41.6 & 2.71 & 0.887 \\
\hline Malondialdehyde (MDA) & $21.3^{a}$ & $15.7^{a, b}$ & $11.1^{\mathrm{b}}$ & 2.40 & 0.043 \\
\hline \multicolumn{6}{|l|}{ Fish welfare indicators } \\
\hline Glucose & 3.33 & 3.69 & 3.23 & 0.19 & 0.319 \\
\hline Lactate & 1.85 & 2.38 & 2.53 & 0.32 & 0.540 \\
\hline
\end{tabular}

C: control diet (no IM inclusion); H18: 18\% HI inclusion; T18: 18\% TM inclusion. SOD and CAT expressed as $\mathrm{U} / \mathrm{mg}$ protein; GPX, GR and G6PDH as $\mathrm{mU} / \mathrm{mg}$ protein; MDA as nmol/g tissue; Glucose and lactate as mmol/L. $\mathrm{a}, \mathrm{b}$ show statistically significant differences among diets $(p<0.05)$. Values are expressed as mean \pm standard error of the mean (SEM; $n=4$ tanks per diet, 2 fish per tank).

The antioxidant system is a complex biochemical structure composed of several molecules and enzymes that fight against the derived toxicity of reactive oxygen species (ROS) resulting from cellular metabolic processes. Roughly, SOD, CAT, and GPx are involved as direct defensive mechanisms against ROS, while GR regenerates the substrate of GPx (glutathione) and G6PDH works on the maintenance of this system by providing NADPH, which is used as a fuel to allow the activity of GR. An imbalance between ROS production and antioxidant mechanisms derivate in oxidative stress, resulting in cellular membrane lipids damage. MDA is a product formed from the breakdown of polyunsaturated fatty acids due to lipid peroxidation, and it may be used as a marker of 
cellular damage [105]. Because all these molecules work together to prevent oxidative injury, it is not strange to find coincidences in their activities, such as the ones shown between SOD and CAT, higher on T18, as well as its consequential MDA decrease on T18. This would also be in consonance with the previously mentioned results of plasmatic acid phosphatase, because a more efficient antioxidant system should be reflected on a lesser amount of cellular damage. In general, the current bibliography strongly supports the idea that IMs help to prevent the derived toxicity of oxygen in two different ways: indirectly, by enhancing the antioxidant system, or directly, by preventing the oxidative damage itself. The first case can be easily recognized in those experiences where higher activities of antioxidant elements are highlighted, ideally, but not always, followed by a consequential decrease in the concentration of oxidative damage indicators (typically, MDA) when a significant amount of IM is added to the diet [21,30-32]. The second case can be more complicated, because the mechanisms that regulate the reduction of oxidative damage through the addition of IMs are not yet well known. As previously stated for the immunological system, a frequent hypothesis used to justify this involves the activity of chitin and its derivates in fish physiology, because it was described that this molecule could produce a direct scavenging effect on radical species, as well as an increase in intracellular glutathione [29]. The work of Moutinho [20] described a decrease in both SOD and CAT activities and a lower concentration of MDA on European seabass liver after an increasing amount of HI was added to the diet, suggesting this preventive effect. Moreover, the work of Sánchez-Muros on tilapia [106] described an increase in liver SOD activity, muscle ROS, and intestine ferric-reducing antioxidant power for a diet based on FM and soy meal, while two experimental diets with TM meals produced the opposite effects, even though one of them had the same amount of soy meal as the first, giving again the idea of a preventive effect. Interestingly, the work of $\mathrm{Xu}$ [104] highlighted an increase in SOD activity in the liver of juvenile mirror carp after the administration of $\mathrm{HI}$ oil, which suggests that chitin might not be the only element involved in the enhancement of the antioxidant system of fish after using whole IMs.

Glucose and lactate are known to be indicators of animal welfare, because their levels in plasma are increased after stressful situations [107-109]. Other trials based on the evaluation of IMs as ingredients for fish compared the levels of plasmatic glucose, but in general, not many changes have been described $[110,111]$. The present study matched this case; on the one hand, this means that the fish homeostasis was correct and compensated even in those cases where other indicators (acid phosphatase and MDA) suggested the presence of tissue damage; on the other hand, IMs did not affect either of these animal welfare indicators in a positive way.

\subsection{Proximate Composition of the Fillet}

The proximate composition of rainbow trout fillets was appointed in Table 8. Moisture levels were lower for T18 than for C. Protein and ash levels were higher for insect-based treatments than for $\mathrm{C}$ diet, while fat showed no significant differences. Despite the lower values of phosphorus in IMs, the phosphorus content in the fillets was similar among treatments, so IMs were able to satisfy the nutritional requirements.

In general, dry components were higher on fillets of fish fed with insect-based diets. Several studies have evaluated the composition of rainbow trout fillets after a growth trial with HI and TM IMs. Some of them described no differences in fish fillet compositions $[62,67,112]$, while others described small changes in raw protein or lipids, the decrease on these parameters being more frequent than the opposite trend $[61,65,113]$. However, all the cited manuscripts describe experiences with bigger sizes of rainbow trout than those used for the present study. Our previous study [32] did not show any differences on fillet protein, fat, or ash, which means that the increased inclusion of HI and TM in the diets (18\% vs. $5 / 10 \%$ ) may have played an important role on these changes. Considering this, it is possible that smaller fish could have dealt differently with higher amounts of IMs, contrary to what was described for bigger fish. 
Table 8. Proximate composition of fillets of rainbow trout fed experimental diets.

\begin{tabular}{cccccc}
\hline $\begin{array}{c}\text { Proximate Composition of the } \\
\begin{array}{c}\text { Fillet } \\
\text { (Wet Basis) }\end{array}\end{array}$ & C & H18 & T18 & SEM & $p$-Value \\
\hline Moisture (\%) & $77.6^{\mathrm{a}}$ & $77.2^{\mathrm{a}, \mathrm{b}}$ & $76.4^{\mathrm{b}}$ & 0.24 & 0.017 \\
Protein (\%) & $18.2^{\mathrm{b}}$ & $19.6^{\mathrm{a}}$ & $19.5^{\mathrm{a}}$ & 0.24 & 0.006 \\
Fat (\%) & 1.09 & $1.87^{\mathrm{a}}$ & 1.52 & 0.21 & 0.070 \\
Ash (\%) & $1.29^{\mathrm{b}}$ & $1.42^{\mathrm{a}}$ & $1.38^{\mathrm{a}}$ & 0.01 & 0.0001 \\
Calcium (mg/Kg) & 325.4 & 418.0 & 400.0 & 46.2 & 0.365 \\
Phosphorus (g/Kg) & 2.98 & 2.92 & 2.96 & 0.06 & 0.813 \\
\hline
\end{tabular}

C: control diet (no IM inclusion); H18: 18\% HI inclusion; T18: 18\% TM inclusion. ${ }^{\mathrm{a}, \mathrm{b}}$ Show statistically significan differences among diets $(p<0.05)$. Values are expressed as mean \pm standard error of the mean (SEM; $n=4$ tanks per diet, 2 fish per tank).

\section{Conclusions}

This study shows the importance of adequately selecting a type of IM before its inclusion as an ingredient in aquafeeds. Although in terms of absolute values for growth performance, the use of HI or TM in feeds for rainbow trout was efficient, fish fed with TM grew better than fish fed with HI. These differences have been marked by the higher use of the protein and more active digestive function, supported with intestinal histological changes observed, particularly the increase in villi height for T18. It is also remarkable that a small increase in enterocyte height was described for insect-based diets, which could be related to the different absorption of insect fat.

No changes were noticed for liver histology or intermediary metabolism. The antioxidant and immunological systems suffered a slight activity improvement for insect-based diets reflected on the decrease in tissue damage indicators (MDA and acid phosphatase), but this did not modify the overall health and welfare status of fish. Although more research is encouraged to isolate and identify the specific physiological mechanisms that make IMs improve the performance of both the antioxidant and the immunological systems of fish, this study supports the idea that IMs act as potential functional ingredients.

Minor changes in the composition of the fillets were observed, with a higher amount of protein in fish fed with insects. More research is encouraged to elucidate the long-term feeding effects.

Author Contributions: Conceptualization, H.J.P., G.C., F.G.B. and C.T.-A.; data curation, F.M. and C.T.-A.; formal analysis, F.M. and C.T.-A.; funding acquisition, H.J.P., G.C., F.G.B. and C.T.-A.; investigation, C.T.-A.; methodology, F.M., E.d.M., H.J.P., G.C., D.F., H.M.L., M.-F.P., L.L., P.W., M.C. and C.T.-A.; project administration, C.T.-A.; supervision, F.M.; writing-original draft, F.M. and C.T.-A.; writing-review and editing, F.M. and C.T.-A. All authors have read and agreed to the published version of the manuscript.

Funding: This research was funded by 'Instituto Nacional de Investigación Agraria y Alimentaria', cofunded by European Regional Development Fund, grant number RTA 2015-00021-C03. The 'Agencia Estatal de Investigación-Ministerio de Ciencia e Innovación' supports the PhD contract of F.M., grant number BES2017-080567, cofunded by European Social Funds.

Institutional Review Board Statement: The study was conducted according to the guidelines of the Declaration of Helsinki, and approved by the Institutional Review Board (or Ethics Committee) of Instituto Tecnológico Agrario de Castilla y León (protocol code 2017/19/CEEA and date of approval 16 March 2017).

Informed Consent Statement: Not applicable.

Data Availability Statement: The data presented in this study are available in the article.

Acknowledgments: The authors would like to thank LifeBIOENCAPSULATION S.L. for the support in the feed formulation, as well as Luis Mercado for kindly donating some of the necessary reagents for the TNF- $\alpha$ analyses. 
Conflicts of Interest: The authors declare no conflict of interest.

\section{References}

1. United Nations, Department of Economic and Social Affairs, Population Division. World Population Prospects 2019: Highlights; United Nations: New York, NY, USA, 2019; p. 40.

2. Fry, J.P.; A Mailloux, N.; Love, D.C.; Milli, M.C.; Cao, L. Feed conversion efficiency in aquaculture: Do we measure it correctly? Environ. Res. Lett. 2018, 13, 024017. [CrossRef]

3. FAO. The State of World Fisheries and Aquaculture 2020. In Sustainability in Action; FAO: Rome, Italy, 2020. [CrossRef]

4. Tacon, A.G.J.; Metian, M. Global overview on the use of fish meal and fish oil in industrially compounded aquafeeds: Trends and future prospects. Aquaculture 2008, 285, 146-158. [CrossRef]

5. Tomás-Almenar, C.; Toledo-Solís, F.J.; Larrán, A.M.; De Mercado, E.; Alarcón, F.J.; Rico, D.; Martín-Diana, A.B.; Fernández, I. Effects and Safe Inclusion of Narbonne Vetch (Vicia narbonensis) in Rainbow Trout (Oncorhynchus mykiss) Diets: Towards a More Sustainable Aquaculture. Animals 2020, 10, 2175. [CrossRef] [PubMed]

6. He, Y.; Guo, X.; Tan, B.; Dong, X.; Yang, Q.; Liu, H.; Zhang, S.; Chi, S. Replacing fish meal with fermented rice protein in diets for hybrid groupers (Epinephelus fuscoguttatus $\times$ Epinephelus lanceolatus): Effects on growth, digestive and absorption capacities, inflammatory-related gene expression, and intestinal microbiota. Aquaculture Rep. 2021, 19, 100603. [CrossRef]

7. Øverland, M.; Skrede, A. Yeast derived from lignocellulosic biomass as a sustainable feed resource for use in aquaculture. J. Sci. Food Agric. 2017, 97, 733-742. [CrossRef]

8. Agboola, J.O.; Schiavone, M.; Øverland, M.; Morales-Lange, B.; Lagos, L.; Arntzen, M.Ø.; Lapeña, D.; Eijsink, V.G.H.; Horn, S.J.; Mydland, L.T.; et al. Author Correction: Impact of down-stream processing on functional properties of yeasts and the implications on gut health of Atlantic salmon (Salmo salar). Sci. Rep. 2021, 11, 1-2. [CrossRef] [PubMed]

9. Alagawany, M.; Taha, A.E.; Noreldin, A.; El-Tarabily, K.A.; El-Hack, M.E.A. Nutritional applications of species of Spirulina and Chlorella in farmed fish: A review. Aquaculture 2021, 542, 736841. [CrossRef]

10. Serrano, E.; Simpfendorfer, R.; Medina, A.; Sandoval, C.; Martínez, A.; Morales, R.; Davies, S.J. Partially replacing fish oil with microalgae (Schizochytrium limacinum and Nannochloropsis oceanica) in diets for rainbow trout (Oncorhynchus mykiss) reared in saltwater with reference to growth performance, muscle fatty acid composition and liver ultrastructure. Aquac. Res. 2021, 52, 4401-4413. [CrossRef]

11. Tran, G.; Heuzé, V.; Makkar, H.P.S. Insects in Fish Diets. Animals Front. 2015, 5, 37-44. [CrossRef]

12. Gasco, L.; Acuti, G.; Bani, P.; Dalle Zotte, A.; Danieli, P.P.; De Angelis, A.; Fortina, R.; Marino, R.; Parisi, G.; Piccolo, G.; et al. Insect and fish by-products as sustainable alternatives to conventional animal proteins in animal nutrition. Ital. J. Animals Sci. 2020, 19, 360-372. [CrossRef]

13. Mousavi, S.; Zahedinezhad, S.; Loh, J.Y. A review on insect meals in aquaculture: The immunomodulatory and physiological effects. Int. Aquat. Res 2020, 12, 100-115.

14. Shafique, L.; Abdel-Latif, H.; Hassan, F.-U.; Alagawany, M.; Naiel, M.; Dawood, M.; Yilmaz, S.; Liu, Q. The Feasibility of Using Yellow Mealworms (Tenebrio molitor): Towards a Sustainable Aquafeed Industry. Animals 2021, 11, 811. [CrossRef]

15. Rodjaroen, S.; Thongprajukaew, K.; Khongmuang, P.; Malawa, S.; Tuntikawinwong, K.; Saekhow, S. Ontogenic Development of Digestive Enzymes in Mealworm Larvae (Tenebrio molitor) and Their Suitable Harvesting Time for Use as Fish Feed. Insects 2020, 11, 393. [CrossRef]

16. Barroso, F.G.; de Haro, C.; Sánchez-Muros, M.-J.; Venegas, E.; Martínez-Sánchez, A.; Pérez-Bañón, C. The potential of various insect species for use as food for fish. Aquaculture 2014, 422-423, 193-201. [CrossRef]

17. Makkar, H.P.; Tran, G.; Heuzé, V.; Ankers, P. State-of-the-art on use of insects as animal feed. Animals Feed Sci. Technol. 2014, 197, 1-33. [CrossRef]

18. Van Huis, A. Potential of Insects as Food and Feed in Assuring Food Security. Annu. Rev. Ėntomol. 2013, 58, 563-583. [CrossRef]

19. Food and Agriculture Organization of the United Nations. Factsheets on the 21 SDG Indicators under FAO Custodianship—A Highlight of the Main Indicators with the Greatest Gaps in Country Reporting; Food and Agriculture Organization of the United Nations: Rome, Italy, 2020.

20. Moutinho, S.; Pedrosa, R.; Magalhães, R.; Oliva-Teles, A.; Parisi, G.; Peres, H. Black soldier fly (Hermetia illucens) pre-pupae larvae meal in diets for European seabass (Dicentrarchus labrax) juveniles: Effects on liver oxidative status and fillet quality traits during shelf-life. Aquaculture 2021, 533, 736080. [CrossRef]

21. Li, S.; Ji, H.; Zhang, B.; Zhou, J.; Yu, H. Defatted black soldier fly (Hermetia illucens) larvae meal in diets for juvenile Jian carp (Cyprinus carpio var. Jian): Growth performance, antioxidant enzyme activities, digestive enzyme activities, intestine and hepatopancreas histological structure. Aquaculture 2017, 477, 62-70. [CrossRef]

22. Guerreiro, I.; Castro, C.; Antunes, B.; Coutinho, F.; Rangel, F.; Couto, A.; Serra, C.; Peres, H.; Pousão-Ferreira, P.; Matos, E.; et al. Catching black soldier fly for meagre: Growth, whole-body fatty acid profile and metabolic responses. Aquaculture 2020, 516, 734613. [CrossRef]

23. Coutinho, F.; Castro, C.; Guerreiro, I.; Rangel, F.; Couto, A.; Serra, C.R.; Peres, H.; Pousão-Ferreira, P.; Rawski, M.; Oliva-Teles, A.; et al. Mealworm larvae meal in diets for meagre juveniles: Growth, nutrient digestibility and digestive enzymes activity. Aquaculture 2021, 535, 736362. [CrossRef] 
24. Tilami, S.K.; Turek, J.; Červený, D.; Lepič, P.; Kozák, P.; Burkina, V.; Sakalli, S.; Tomčala, A.; Sampels, S.; Mráz, J. Insect Meal as a Partial Replacement for Fish Meal in a Formulated Diet for Perch Perca fluviatilis. Turk. J. Fish. Aquat. Sci. 2020, 20, 867-878. [CrossRef]

25. Terova, G.; Rimoldi, S.; Ascione, C.; Gini, E.; Ceccotti, C.; Gasco, L. Rainbow trout (Oncorhynchus mykiss) gut microbiota is modulated by insect meal from Hermetia illucens prepupae in the diet. Rev. Fish Biol. Fish. 2019, 29, 465-486. [CrossRef]

26. Belghit, I.; Liland, N.S.; Gjesdal, P.; Biancarosa, I.; Menchetti, E.; Li, Y.; Waagbo, R.; Krogdahl, Å.; Lock, E.-J. Black soldier fly larvae meal can replace fish meal in diets of sea-water phase Atlantic salmon (Salmo salar). Aquaculture 2019, 503, 609-619. [CrossRef]

27. Mikołajczak, Z.; Rawski, M.; Mazurkiewicz, J.; Kierończyk, B.; Józefiak, D. The Effect of Hydrolyzed Insect Meals in Sea Trout Fingerling (Salmo trutta m. trutta) Diets on Growth Performance, Microbiota and Biochemical Blood Parameters. Animals 2020, 10, 1031. [CrossRef] [PubMed]

28. Chemello, G.; Renna, M.; Caimi, C.; Guerreiro, I.; Oliva-Teles, A.; Enes, P.; Biasato, I.; Schiavone, A.; Gai, F.; Gasco, L. Partially Defatted Tenebrio molitor Larva Meal in Diets for Grow-Out Rainbow Trout, Oncorhynchus mykiss (Walbaum): Effects on Growth Performance, Diet Digestibility and Metabolic Responses. Animals 2020, 10, 229. [CrossRef] [PubMed]

29. Ngo, D.-H.; Kim, S.-K. Chapter Two-Antioxidant Effects of Chitin, Chitosan, and Their Derivatives. Adv. Food Nutr. Res. 2014, 73, 15-31. [PubMed]

30. Henry, M.; Gai, F.; Enes, P.; Peréz-Jiménez, A.; Gasco, L. Effect of partial dietary replacement of fishmeal by yellow mealworm (Tenebrio molitor) larvae meal on the innate immune response and intestinal antioxidant enzymes of rainbow trout (Oncorhynchus mykiss). Fish Shellfish. Immunol. 2018, 83, 308-313. [CrossRef] [PubMed]

31. Xu, X.; Ji, H.; Yu, H.; Zhou, J. Influence of dietary black soldier fly (Hermetia illucens Linnaeus) pulp on growth performance, antioxidant capacity and intestinal health of juvenile mirror carp (Cyprinus carpio var. specularis). Aquac. Nutr. 2019, 26, 432-443. [CrossRef]

32. Melenchón, F.; Larrán, A.; de Mercado, E.; Hidalgo, M.; Cardenete, G.; Barroso, F.; Fabrikov, D.; Lourenço, H.; Pessoa, M.; Tomás-Almenar, C. Potential use of black soldier fly (Hermetia illucens) and mealworm (Tenebrio molitor) insectmeals in diets for rainbow trout (Oncorhynchus mykiss). Aquac. Nutr. 2021, 27, 491-505. [CrossRef]

33. Weththasinghe, P.; Lagos, L.; Cortés, M.; Hansen, J. Øvrum; Øverland, M. Dietary Inclusion of Black Soldier Fly (Hermetia Illucens) Larvae Meal and Paste Improved Gut Health but Had Minor Effects on Skin Mucus Proteome and Immune Response in Atlantic Salmon (Salmo salar). Front. Immunol. 2021, 12, 599530. [CrossRef]

34. European Parliament. Commission Regulation 2017/893/EU of 24 May 2017 Amending Annexes I and IV to Regulation (EC) No 999/2001 of the European Parliament and of the Council and Annexes X, XIV and XV to Commission Regulation (EU) No 142/2011 as Regards the Provisions on Processed Animal Protein; European Parliament: Strasbourg, France, 2017; pp. 92-116.

35. Blanco Cachafeiro, M.C. La Trucha: Cría Industrial, 2nd ed.; Mundi-Prensa: Madrid, Spain, 2005.

36. National Research Council. Nutrient Requirements of Fish; National Academies Press: Washington, DC, USA, 1993.

37. European Parliament. Book Directive 2010/63/EU of the European Parliament and of the Council of 22 September 2010 on the Protection of Animals Used for Scientific Purposes; European Parliament: Strasbourg, France, 2010; pp. 33-78.

38. Real Decreto 53/2013, de 1 de Febrero, Por el Que se Establecen las Normas Básicas Aplicables para la Protección de Los Animales Utilizados en Experimentación y Otros Fines Científicos, Incluyendo la Docencia. 2013. Available online: https: //www.boe.es/eli/es/rd/2013/02/01/53 (accessed on 16 December 2021).

39. Cho, C.; Slinger, S.; Bayley, H. Bioenergetics of salmonid fishes: Energy intake, expenditure and productivity. Comp. Biochem. Physiol. Part B Comp. Biochem. 1982, 73, 25-41. [CrossRef]

40. De Mercado, E.; Larrán, A.M.; Pinedo, J.; Tomás-Almenar, C. Skin mucous: A new approach to assess stress in rainbow trout. Aquaculture 2018, 484, 90-97. [CrossRef]

41. Bradford, M.M. A rapid and sensitive method for the quantitation of microgram quantities of protein utilizing the principle of protein-dye binding. Anal. Biochem. 1976, 72, 248-254. [CrossRef]

42. AOAC. Official Methods of Analysis of the Association of Official Analytical Communities International, 18th ed.; AOAC: Rockville, MD, USA, 2005.

43. Saint-Denis, T.; Goupy, J. Optimization of a nitrogen analyser based on the Dumas method. Anal. Chim. Acta 2004, 515, 191-198. [CrossRef]

44. Janssen, R.H.; Vincken, J.-P.; van den Broek, L.A.M.; Fogliano, V.; Lakemond, C.M.M. Nitrogen-to-Protein Conversion Factors for Three Edible Insects: Tenebrio molitor, Alphitobius diaperinus, and Hermetia illucens. J. Agric. Food Chem. 2017, 65, $2275-2278$. [CrossRef]

45. Atkinson, J.L.; Hilton, J.W.; Slinger, S.J. Evaluation of Acid-Insoluble Ash as an Indicator of Feed Digestibility in Rainbow Trout (Salmo gairdneri). Can. J. Fish. Aquat. Sci. 1984, 41, 1384-1386. [CrossRef]

46. ISO 13730. Meat and Meat Products—Determination of Total Phosphorus Content-Spectrometric Method: ISO Technical Committee TC 34/SC 6; ISO: Geneva, Switzerland, 1996.

47. Pessoa, M.; Campos, P.S.; Pais, I.; Feteiro, A.; Canuto, D.; Simões, M.; Pelica, J.; Pataco, I.; Ribeiro, V.S.; Ramalho, J.C.; et al. Nutritional profile of the Portuguese cabbage (Brassica oleracea L var. costata) and its relationship with the elemental soil analysis. Emir. J. Food Agric. 2016, 28, 381-388. [CrossRef]

48. Gamage, A.; Shahidi, F. Use of chitosan for the removal of metal ion contaminants and proteins from water. Food Chem. 2007, 104, 989-996. [CrossRef] 
49. Somogyi, M. Notes on Sugar Determination. J. Biol. Chem. 1952, 195, 19-23. [CrossRef]

50. Walter, H.E. Proteinases: Methods with Hemoglobin, Casein and Azocoll as Substrates. In Methods of Enzymatic Analysis; Bergmeyer, H.J., Ed.; Elsevier: Amsterdam, The Netherlands, 1984; Volume 5, pp. 270-277.

51. Anson, M.L. The Estimation of Pepsin, Trypsin, Papain, And Cathepsin with Hemoglobin. J. Gen. Physiol. 1938, 22, 79-89. [CrossRef]

52. Furné, M.; Morales, A.E.; Trenzado, C.E.; García-Gallego, M.; Hidalgo, M.C.; Domezain, A.; Rus, A.S. The metabolic effects of prolonged starvation and refeeding in sturgeon and rainbow trout. J. Comp. Physiol. B 2011, 182, 63-76. [CrossRef]

53. Swain, P.; Dash, S.; Sahoo, P.K.; Routray, P.; Sahoo, S.; Gupta, S.D.; Meher, P.K.; Sarangi, N. Non-specific immune parameters of brood Indian major carp Labeo rohita and their seasonal variations. Fish Shellfish Immunol. 2007, 22, 38-43. [CrossRef]

54. Mashiter, K.E.; Morgan, M. Carbonic anhydrase levels in the tissues of flounders adapted to sea water and fresh water. Comp. Biochem. Physiol. Part A Physiol. 1975, 52, 713-717. [CrossRef]

55. Thompson, I.; Choubert, G.; Houlihan, D.; Secombes, C. The effect of dietary vitamin A and astaxanthin on the immunocompetence of rainbow trout. Aquaculture 1995, 133, 91-102. [CrossRef]

56. Huang, Z.-H.; Ma, A.-J.; Wang, X.-A. The immune response of turbot, Scophthalmus maximus (L.), skin to high water temperature. J. Fish Dis. 2011, 34, 619-627. [CrossRef]

57. Mohanty, B.; Sahoo, P. Immune responses and expression profiles of some immune-related genes in Indian major carp, Labeo rohita to Edwardsiella tarda infection. Fish Shellfish. Immunol. 2010, 28, 613-621. [CrossRef]

58. Panigrahi, A.; Kiron, V.; Puangkaew, J.; Kobayashi, T.; Satoh, S.; Sugita, H. The viability of probiotic bacteria as a factor influencing the immune response in rainbow trout Oncorhynchus mykiss. Aquaculture 2005, 243, 241-254. [CrossRef]

59. Morales, B.; Bethke, J.; Schmitt, P.; Mercado, L. Phenotypical parameters as a tool to evaluate the immunostimulatory effects of laminarin in Oncorhynchus mykiss. Aquac. Res. 2014, 46, 2707-2715. [CrossRef]

60. Pérez-Jiménez, A.; Hidalgo, M.C.; Morales, A.E.; Arizcun, M.; Abellán, E.; Cardenete, G. Antioxidant enzymatic defenses and oxidative damage in Dentex dentex fed on different dietary macronutrient levels. Comp. Biochem. Physiol. Part C Toxicol. Pharmacol. 2009, 150, 537-545. [CrossRef]

61. Sealey, W.M.; Gaylord, T.G.; Barrows, F.T.; Tomberlin, J.K.; McGuire, M.A.; Ross, C.; St-Hilaire, S. Sensory Analysis of Rainbow Trout, Oncorhynchus mykiss, Fed Enriched Black Soldier Fly Prepupae, Hermetia illucens. J. World Aquaculture Soc. 2011, 42, 34-45. [CrossRef]

62. Borgogno, M.; Dinnella, C.; Iaconisi, V.; Fusi, R.; Scarpaleggia, C.; Schiavone, A.; Monteleone, E.; Gasco, L.; Parisi, G. Inclusion of Hermetia illucens larvae meal on rainbow trout (Oncorhynchus mykiss) feed: Effect on sensory profile according to static and dynamic evaluations. J. Sci. Food Agric. 2017, 97, 3402-3411. [CrossRef] [PubMed]

63. Jozefiak, A.; Nogales-Mérida, S.; Mikołajczak, Z.; Rawski, M.; Kierończyk, B.; Mazurkiewicz, J. The Utilization of Full-Fat Insect Meal in Rainbow Trout (Oncorhynchus mykiss) Nutrition: The Effects on Growth Performance, Intestinal Microbiota and Gastrointestinal Tract Histomorphology. Ann. Animals Sci. 2019, 19, 747-765. [CrossRef]

64. Caimi, C.; Renna, M.; Lussiana, C.; Bonaldo, A.; Gariglio, M.; Meneguz, M.; Dabbou, S.; Schiavone, A.; Gai, F.; Elia, A.C.; et al. First insights on Black Soldier Fly (Hermetia illucens L.) larvae meal dietary administration in Siberian sturgeon (Acipenser baerii Brandt) juveniles. Aquaculture 2020, 515, 734539. [CrossRef]

65. Belforti, M.; Gai, F.; Lussiana, C.; Renna, M.; Malfatto, V.; Rotolo, L.; De Marco, M.; Dabbou, S.; Schiavone, A.; Zoccarato, I.; et al Tenebrio molitor meal in rainbow trout (Oncorhynchus mykiss) diets: Effects on animal performance, nutrient digestibility and chemical composition of fillets. Ital. J. Animals Sci. 2015, 14, 4170. [CrossRef]

66. Iaconisi, V.; Bonelli, A.; Pupino, R.; Gai, F.; Parisi, G. Mealworm as dietary protein source for rainbow trout: Body and fillet quality traits. Aquaculture 2018, 484, 197-204. [CrossRef]

67. Dumas, A.; Raggi, T.; Barkhouse, J.; Lewis, E.; Weltzien, E. The oil fraction and partially defatted meal of black soldier fly larvae (Hermetia illucens) affect differently growth performance, feed efficiency, nutrient deposition, blood glucose and lipid digestibility of rainbow trout (Oncorhynchus mykiss). Aquaculture 2018, 492, 24-34. [CrossRef]

68. Kumar, R.; Kaur, N.; Kamilya, D. Chitin modulates immunity and resistance of Labeo rohita (Hamilton, 1822) against gill monogeneans. Aquaculture 2019, 498, 522-527. [CrossRef]

69. Kroeckel, S.; Harjes, A.-G.; Roth, I.; Katz, H.; Wuertz, S.; Susenbeth, A.; Schulz, C. When a turbot catches a fly: Evaluation of a pre-pupae meal of the Black Soldier Fly (Hermetia illucens) as fish meal substitute-Growth performance and chitin degradation in juvenile turbot (Psetta maxima). Aquaculture 2012, 364-365, 345-352. [CrossRef]

70. Marono, S.; Piccolo, G.; Loponte, R.; Di Meo, C.; Attia, Y.A.; Nizza, A.; Bovera, F. In Vitro Crude Protein Digestibility of Tenebrio Molitor and Hermetia Illucens Insect Meals and its Correlation with Chemical Composition Traits. Ital. J. Animals Sci. 2015, 14, 3889. [CrossRef]

71. Cardinaletti, G.; Randazzo, B.; Messina, M.; Zarantoniello, M.; Giorgini, E.; Zimbelli, A.; Bruni, L.; Parisi, G.; Olivotto, I.; Tulli, F. Effects of Graded Dietary Inclusion Level of Full-Fat Hermetia illucens Prepupae Meal in Practical Diets for Rainbow Trout (Oncorhynchus mykiss). Animals 2019, 9, 251. [CrossRef]

72. Gupta, S.K.; Fotedar, R.; Foysal, J.; Priyam, M.; Siddik, M.A.B.; Chaklader, R.; Dao, T.T.T.; Howieson, J. Impact of varied combinatorial mixture of non-fishmeal ingredients on growth, metabolism, immunity and gut microbiota of Lates calcarifer (Bloch, 1790) fry. Sci. Rep. 2020, 10, 1-13. [CrossRef] 
73. Basto, A.; Calduch-Giner, J.; Oliveira, B.; Petit, L.; Sá, T.; Maia, M.R.G.; Fonseca, S.C.; Matos, E.; Pérez-Sánchez, J.; Valente, L.M.P. The Use of Defatted Tenebrio molitor Larvae Meal as a Main Protein Source Is Supported in European Sea Bass (Dicentrarchus labrax) by Data on Growth Performance, Lipid Metabolism, and Flesh Quality. Front. Physiol. 2021, 12, 659567. [CrossRef]

74. Chaklader, R.; Howieson, J.; Siddik, M.A.B.; Foysal, J.; Fotedar, R. Supplementation of tuna hydrolysate and insect larvae improves fishmeal replacement efficacy of poultry by-product in Lates calcarifer (Bloch, 1790) juveniles. Sci. Rep. 2021, 11, 1-20. [CrossRef]

75. Vargas-Abúndez, A.J.; Randazzo, B.; Foddai, M.; Sanchini, L.; Truzzi, C.; Giorgini, E.; Gasco, L.; Olivotto, I. Insect meal based diets for clownfish: Biometric, histological, spectroscopic, biochemical and molecular implications. Aquaculture 2019, $498,1-11$. [CrossRef]

76. Lu, R.; Chen, Y.; Yu, W.; Lin, M.; Yang, G.; Qin, C.; Meng, X.; Zhang, Y.; Ji, H.; Nie, G. Defatted black soldier fly (Hermetia illucens) larvae meal can replace soybean meal in juvenile grass carp (Ctenopharyngodon idellus) diets. Aquac. Rep. 2020, 18, 100520. [CrossRef]

77. Zarantoniello, M.; Randazzo, B.; Nozzi, V.; Truzzi, C.; Giorgini, E.; Cardinaletti, G.; Freddi, L.; Ratti, S.; Girolametti, F.; Osimani, A.; et al. Physiological responses of Siberian sturgeon (Acipenser baerii) juveniles fed on full-fat insect-based diet in an aquaponic system. Sci. Rep. 2021, 11, 1-13. [CrossRef]

78. Zarantoniello, M.; Randazzo, B.; Gioacchini, G.; Truzzi, C.; Giorgini, E.; Riolo, P.; Gioia, G.; Bertolucci, C.; Osimani, A.; Cardinaletti, G.; et al. Zebrafish (Danio rerio) physiological and behavioural responses to insect-based diets: A multidisciplinary approach. Sci. Rep. 2020, 10, 1-16. [CrossRef]

79. Hender, A.; Siddik, M.; Howieson, J.; Fotedar, R. Black Soldier Fly, Hermetia illucens as an Alternative to Fishmeal Protein and Fish Oil: Impact on Growth, Immune Response, Mucosal Barrier Status, and Flesh Quality of Juvenile Barramundi, Lates calcarifer (Bloch, 1790). Biology 2021, 10, 505. [CrossRef]

80. Józefiak, A.; Nogales-Mérida, S.; Rawski, M.; Kierończyk, B.; Mazurkiewicz, J. Effects of insect diets on the gastrointestinal tract health and growth performance of Siberian sturgeon (Acipenser baerii Brandt, 1869). BMC Veter. Res. 2019, 15, 348. [CrossRef]

81. Rawski, M.; Mazurkiewicz, J.; Kierończyk, B.; Józefiak, D. Black Soldier Fly Full-Fat Larvae Meal Is More Profitable Than Fish Meal and Fish Oil in Siberian Sturgeon Farming: The Effects on Aquaculture Sustainability, Economy and Fish GIT Development. Animals 2021, 11, 604. [CrossRef]

82. Romarheim, O.H.; Skrede, A.; Gao, Y.; Krogdahl, Å.; Denstadli, V.; Lilleeng, E.; Storebakken, T. Comparison of white flakes and toasted soybean meal partly replacing fish meal as protein source in extruded feed for rainbow trout (Oncorhynchus mykiss). Aquaculture 2006, 256, 354-364. [CrossRef]

83. Penn, M.H.; Bendiksen, E.Å.; Campbell, P.; Krogdahl, Å. High level of dietary pea protein concentrate induces enteropathy in Atlantic salmon (Salmo salar L.). Aquaculture 2011, 310, 267-273. [CrossRef]

84. Zhang, C.; Rahimnejad, S.; Wang, Y.-R.; Lu, K.; Song, K.; Wang, L.; Mai, K. Substituting fish meal with soybean meal in diets for Japanese seabass (Lateolabrax japonicus): Effects on growth, digestive enzymes activity, gut histology, and expression of gut inflammatory and transporter genes. Aquaculture 2018, 483, 173-182. [CrossRef]

85. Wiles, T.; Jemielita, M.; Baker, R.P.; Schlomann, B.H.; Logan, S.L.; Ganz, J.; Melancon, E.; Eisen, J.S.; Guillemin, K.; Parthasarathy, R. Host Gut Motility Promotes Competitive Exclusion within a Model Intestinal Microbiota. PLoS Biol. 2016, 14, e1002517. [CrossRef]

86. Lignot, J.-H.; Helmstetter, C.; Secor, S.M. Postprandial morphological response of the intestinal epithelium of the Burmese python (Python molurus). Comp. Biochem. Physiol. Part A Mol. Integr. Physiol. 2005, 141, 280-291. [CrossRef]

87. Starck, J.M.; Cruz-Neto, A.; Abe, A.S. Physiological and morphological responses to feeding in broad-nosed caiman (Caiman latirostris). J. Exp. Biol. 2007, 210, 2033-2045. [CrossRef]

88. Kumar, V.; Fawole, F.J.; Romano, N.; Hossain, S.; Labh, S.N.; Overturf, K.; Small, B.C. Insect (black soldier fly, Hermetia illucens) meal supplementation prevents the soybean meal-induced intestinal enteritis in rainbow trout and health benefits of using insect oil. Fish Shellfish Immunol. 2020, 109, 116-124. [CrossRef]

89. Baeverfjord, G.; Krogdahl, A. Development and regression of soybean meal induced enteritis in Atlantic salmon, Salmo salar L., distal intestine: A comparison with the intestines of fasted fish. J. Fish Dis. 1996, 19, 375-387. [CrossRef]

90. Lindsay, G.J.; Walton, M.; Adron, J.; Fletcher, T.C.; Cho, C.; Cowey, C. The growth of rainbow trout (Salmo gairdneri) given diets containing chitin and its relationship to chitinolytic enzymes and chitin digestibility. Aquaculture 1984, 37, 315-334. [CrossRef]

91. German, D.P.; Horn, M.H.; Gawlicka, A. Digestive Enzyme Activities in Herbivorous and Carnivorous Prickleback Fishes (Teleostei: Stichaeidae): Ontogenetic, Dietary, and Phylogenetic Effects. Physiol. Biochem. Zoöl. 2004, 77, 789-804. [CrossRef]

92. Rapatsa, M.; Moyo, N.A. Evaluation of Imbrasia belina meal as a fishmeal substitute in Oreochromis mossambicus diets: Growth performance, histological analysis and enzyme activity. Aquaculture Rep. 2017, 5, 18-26. [CrossRef]

93. Rapatsa, M.M.; Moyo, N.A.G. Enzyme activity and histological analysis of Clarias gariepinus fed on Imbrasia belina meal used for partial replacement of fishmeal. Fish Physiol. Biochem. 2019, 45, 1309-1320. [CrossRef] [PubMed]

94. Mastoraki, M.; Ferrándiz, P.M.; Vardali, S.C.; Kontodimas, D.C.; Kotzamanis, Y.P.; Gasco, L.; Chatzifotis, S.; Antonopoulou, E. A comparative study on the effect of fish meal substitution with three different insect meals on growth, body composition and metabolism of European sea bass (Dicentrarchus labrax L.). Aquaculture 2020, 528, 735511. [CrossRef] 
95. Mastoraki, M.; Vlahos, N.; Patsea, E.; Chatzifotis, S.; Mente, E.; Antonopoulou, E. The effect of insect meal as a feed ingredient on survival, growth, and metabolic and antioxidant response of juvenile prawn Palaemon adspersus (Rathke, 1837). Aquaculture Res. 2020, 51, 3551-3562. [CrossRef]

96. Alejo, A.; Tafalla, C. Chemokines in teleost fish species. Dev. Comp. Immunol. 2011, 35, 1215-1222. [CrossRef] [PubMed]

97. Grosell, M.; Farrell, A.P.; Brauner, C.J. Fish Physiology: The Multifunctional Gut of Fish; Academic Press: Cambridge, MA, USA, 2010.

98. Subramanian, S.; Ross, N.W.; MacKinnon, S.L. Comparison of antimicrobial activity in the epidermal mucus extracts of fish. Comp. Biochem. Physiol. Part B Biochem. Mol. Biol. 2008, 150, 85-92. [CrossRef] [PubMed]

99. Molina, R.; Moreno, I.; Pichardo, S.; Jos, A.; Moyano, R.; Monterde, J.; Cameán, A. Acid and alkaline phosphatase activities and pathological changes induced in Tilapia fish (Oreochromis sp.) exposed subchronically to microcystins from toxic cyanobacterial blooms under laboratory conditions. Toxicon 2005, 46, 725-735. [CrossRef]

100. Moreno, I.M.; Mate, A.; Repetto, G.; Vázquez, C.M.; Cameán, A.M. Influence of Microcystin-LR on the activity of membrane enzymes in rat intestinal mucosa. J. Physiol. Biochem. 2003, 59, 293-299. [CrossRef]

101. Alves, A.P.D.C.; Paulino, R.R.; Pereira, R.T.; Da Costa, D.V.; E Rosa, P.V. Nile tilapia fed insect meal: Growth and innate immune response in different times under lipopolysaccharide challenge. Aquaculture Res. 2021, 52, 529-540. [CrossRef]

102. Tippayadara, N.; Dawood, M.; Krutmuang, P.; Hoseinifar, S.; Doan, H.; Paolucci, M. Replacement of Fish Meal by Black Soldier Fly (Hermetia illucens) Larvae Meal: Effects on Growth, Haematology, and Skin Mucus Immunity of Nile Tilapia, Oreochromis niloticus. Animals 2021, 11, 193. [CrossRef]

103. Vogel, H.; Müller, A.; Heckel, D.; Gutzeit, H.; Vilcinskas, A. Nutritional immunology: Diversification and diet-dependent expression of antimicrobial peptides in the black soldier fly Hermetia illucens. Dev. Comp. Immunol. 2018, 78, 141-148. [CrossRef]

104. Xu, X.; Ji, H.; Belghit, I.; Liland, N.S.; Wu, W.; Li, X. Effects of black soldier fly oil rich in n-3 HUFA on growth performance, metabolism and health response of juvenile mirror carp (Cyprinus carpio var. specularis). Aquaculture 2021, 533, 736144. [CrossRef]

105. Grotto, D.; Maria, L.S.; Valentini, J.; Paniz, C.; Schmitt, G.; Garcia, S.; Pomblum, V.J.; da Rocha, J.B.T.; Farina, M. Importance of the lipid peroxidation biomarkers and methodological aspects FOR malondialdehyde quantification. Quimica Nova 2009, 32, 169-174. [CrossRef]

106. Sánchez-Muros, M.J.; De Haro, C.; Sanz, A.; Trenzado, C.E.; Villareces, S.; Barroso, F.G. Nutritional evaluation ofTenebrio molitormeal as fishmeal substitute for tilapia (Oreochromis niloticus) diet. Aquac. Nutr. 2016, 22, 943-955. [CrossRef]

107. Acerete, L.; Reig, L.; Alvarez, D.; Flos, R.; Tort, L. Comparison of two stunning/slaughtering methods on stress response and quality indicators of European sea bass (Dicentrarchus labrax). Aquaculture 2009, 287, 139-144. [CrossRef]

108. Naderi, M.; Keyvanshokooh, S.; Salati, A.P.; Ghaedi, A. Effects of dietary vitamin E and selenium nanoparticles supplementation on acute stress responses in rainbow trout (Oncorhynchus mykiss) previously subjected to chronic stress. Aquaculture 2017, 473, 215-222. [CrossRef]

109. Gesto, M. Consistent individual competitive ability in rainbow trout as a proxy for coping style and its lack of correlation with cortisol responsiveness upon acute stress. Physiol. Behav. 2019, 208, 112576. [CrossRef]

110. Tran, H.Q.; Van Doan, H.; Stejskal, V. Does dietary Tenebrio molitor affect swimming capacity, energy use, and physiological responses of European perch Perca fluviatilis? Aquaculture 2021, 539, 736610. [CrossRef]

111. Jeong, S.; Khosravi, S.; Mauliasari, I.R.; Lee, B.; You, S.; Lee, S. Nutritional evaluation of cricket, Gryllus bimaculatus, meal as fish meal substitute for olive flounder, Paralichthys olivaceus, juveniles. J. World Aquaculture Soc. 2021, 52, 859-880. [CrossRef]

112. Mancini, S.; Medina, I.; Iaconisi, V.; Gai, F.; Basto, A.; Parisi, G. Impact of black soldier fly larvae meal on the chemical and nutritional characteristics of rainbow trout fillets. Animals 2018, 12, 1672-1681. [CrossRef]

113. Renna, M.; Schiavone, A.; Gai, F.; Dabbou, S.; Lussiana, C.; Malfatto, V.; Prearo, M.; Capucchio, M.T.; Biasato, I.; Biasibetti, E.; et al. Evaluation of the suitability of a partially defatted black soldier fly (Hermetia illucens L.) larvae meal as ingredient for rainbow trout (Oncorhynchus mykiss Walbaum) diets. J. Animals Sci. Biotechnol. 2017, 8, 57. [CrossRef] 